\title{
İlgili Rivâyetler Yönüinden Hz. Peygamber Döneminde Vahyin Yazımı Meselesi
}

BEKIR TATLI

DR., ÇUKUROVA Ü. İLÂHIYAT FAKÜLTESI

e-posta: btatli@cu.edu.tr / tatlibekir@yahoo.com

\begin{abstract}
The Subject of Writing of the Revelation in Period of Prophet Muhammad in Point of Narrations About It. The Qoran Holy Book which had revealed to last prophet Mohammad was protected by various ways like memory, reading and writing on different materials during his life. One of them is writing of the revelations/verses on some materials like paper, parchment, stone, leaf, bone of animals etc. The Prophet has used very much person for this mission. Ubayy Ibn Kaab and Zayd Ibn Sabit are the well-known names about this subject. In this article we have studied narrations about writing of verses of Quran on various materials in period of the Prophet.
\end{abstract}

\section{key words}

Quran, revelation, writing of revelation, narration, Muhammad

\section{Giriş}

Kur'ân-1 Kerim'in Rasûlullah'a yaklaşık 23 senede nâzil olduğunu biliyoruz. Hadislerin çoğunlukla mana ile rivâyet edilmesine mukabil, âyetler hem ezberlenerek hem de yazıya geçirilmek suretiyle ${ }^{1}$ muhafaza altına alınmış, böylece Kur'ân metni günümüze kadar değişmeden gelebilmiştir. Hz. Peygamber'in çeşitli sebeplerle bazı sahâbeye hadis yazımını yasakladığına dair kaynaklarda bazı rivâyetler vardır. Aynı durum acaba vahiy kâtipliği için de geçerli miydi; yani vahiy malzemesini yazmak isteyen herkese bu izin verilmiş midir yoksa yazması yasaklanan kişiler var mıdır? Bu çalışmada, daha çok ilgili rivâyetlerin durumu ön

1 Bkz. İbn Atiyye, Ebû Muhammed Abdülhak b. Ğâlib el-Endelüsî, el-Muharreru'l-vecîz fì tefsîri'lKitâbi'l-azîz, I, 49, thk. Abdüsselâm Abdüşşâfî Muhammed, I-VI, Beyrut 1422/2001. 
plâna çıkarılarak Rasûlullah zamanında vahiy kitâbetinin nasıl ve ne zaman başladı $\breve{g} 1$, kimlerin bu işte vazifelendirildiği, sistemin nasıl işlediğ $i$ gibi konular üzerinde durulmaya çalışllacaktır. Konunun işlenişinde mümkün oldukça Hz. Peygamber'in hayatta olduğu zaman dilimi ele alınacak ve gerekmedikçe onun vefatını müteakip uygulamaya değinilmeyecektir.

\section{Hz. Peygamber'in Ümmîliği ve Vahyin Yazılma Zorunluluğu}

Kur'ân-1 Kerim'de iki yerde Rasûlullah'ın ümmî olduğu açıça ifade edilir. ${ }^{2}$ Allah'ın bu son elçisinin Peygamber olarak gönderildiği toplum da ümmî vasfiyla anılmıştır. ${ }^{3} \mathrm{Bu}$ kelime, "anneye mensup, anadan doğduğu hal üzere" gibi anlamlar ifade etmekte ve daha çok okuma yazma bilmeme manasında kullanılmaktadır. ${ }^{4} \mathrm{~Hz}$. Peygamber'in okuma-yazma bilmediği hususu Ankebût 29/48. âyetinde şu ifadelerle belirtilmektedir: "Sen bundan (Kur'ân'dan) önce hiçbir kitap okumuyor ve onu să̆ elinle yazmıyordun. Öyle olsaydı bâtıla uyanlar şüpheye düşerlerdi."5 Ayrıca Hz. Peygamber'den: "Biz yazmayı ve hesabı bilmeyen ümmî bir toplumuz."6 şeklinde bir rivâyet de nakledilir. Dolayısıyla nübüvvetin ilk yıllarında hem Hz. Peygamber, hem de gönderildiği toplum ümmî idi ve okumayazma anlamında bir bilgi düzeyine sahip değillerdi. ${ }^{7}$

2 Bkz. A'râf, 7/157, 158.

3 Bkz. Cum'a, 62/2.

4 Bkz. Sâbûnî, Muhammed Ali, et-Tibyân fí ulûmi'l-Kur'ân, s. 68, İstanbul, ts.; Yıldırım, Suat, Oryantalistlerin Yanılgıları, s. 125-126, İstanbul 2003; Demirci, Muhsin, Vahiy Gerçeği, s. 211, İstanbul 1996.

5 Rasûlullah'ın okuma-yazma bilmediğinin vurgulandığı bu âyet aynı zamanda vahyin yazılı olduğu konusunda da delil olarak kullanılmaya müsaittir. Nitekim müsteşrik Theodor Nöldeke de Ankebût, 29/47-48. âyetlerde vahyin tedvin edilmesi (yazıya geçirilmesi) konusuna bir telmih olduğunu ifade etmiştir. Bkz. Nöldeke, Târîhu'l-Kur'ân, s. 237, Beyrut 2004. Ancak Nöldeke'nin konuyla ilgili asıl üzerinde durduğu/vurgu yaptığı nokta kitâbet değil hâfızadır; çünkü o ilerleyen satırlarda bu konu üzerinde daha çok durarak, erken dönemde kitâbetin nadir olduğunu ve her şeyin hâfızada tutulduğunu söylemektedir. Bkz. s. 239.

${ }^{6}$ Bkz. İbn Ebî Şeybe, Ebû Bekr b. Abdillah b. Muhammed el-Kûfî, Kitâbu'l-musannef fill-ehâdîs ve'l-âsâr, II, 322 (no: 9604), I-VII, Riyad 1409; Ahmed, Ebû Abdillah İbn Hanbel eş-Seybânî, Müsned, II, 43 (no: 5017), 52 (no: 5137), I-VI, Misır ts.; Buhârî, Ebû Abdillah Muhammed b. İsmâil el-Cu'fî, Sahîhu'l-Buhârî, Savm 13 (no: 1814); Müslim, Ebû'l-Huseyn Müslim b. elHaccâc el-Kuşeyrî, Sahîhu Müslim, Siyâm 15 (no: 1080), I-V, Beyrut ts.; Nesâî, Ebû Abdirrahman Ahmed b. Șuayb, es-Sünenu'l-kubrâ, II, 74 (no: 2451), III, 447 (no: 5884), I-VI, Beyrut 1411/1991.

7 Ümmîlik kavramıyla ilgili bir değerlendirme için bkz. Yörük, İsmail- Şık, İsmail, "Kelam Açısından Hz. Peygamberin Ümmiliği", Dini Araştırmalar, cilt:7, s.19, ss.173-189, MayısAğustos, Ankara 2004. Montgomery Watt, ümmî kelimesine "Yahudi olmayan, yerli olan" anlamlarını vererek, adı geçen âyetlerde Hz. Muhammed'in tümüyle okuma-yazma bilmediği 
Hz. Peygamber'in ümmî oluşu, inmeye devam eden vahiy malzemesi için önemli bir meseleyi de gün yüzüne çıkarmıştı. Esasen gelen vahiylerin kaybolmaması için namaz içinde ve dışında okunma (tilâvet), ezberlenme (hıfz) gibi yardımcı faktörler vardı. Ancak vahyin aynı zamanda kayıt altına alınması ve yazıya geçirilmesi de gerekiyordu. Çünkü gelen vahiyler her geçen gün biraz daha artıyor, bunların karıştırılmadan sadece hafızalarda korunması gittikçe zorlaşıyordu. Bunun için yapılacak en mantıklı iş, gelen âyetlerin kayda geçirilmesiydi. Hz. Peygamber ümmî olduğu için, gelen vahiyleri bizzat kendisinin yazması söz konusu değildi. $\mathrm{Bu}$ nedenle, vahyin yazıya geçirilmesi için yazma bilen sahâbîlerden yardım alması gerekmiş olmalıdır.

Vahyin yazdırılmaya başlanması kararını Hz. Peygamber ya bizzat kendi tasarrufuyla yahut da Allah'ın Kur'ân'ı koruyacağına dair verdiği teminatla ${ }^{8}$ birlikte Allah'tan aldığ 1 bir vahiy sonucu vermiş olabilir. ${ }^{9} \mathrm{Bu}$ kararın bir sonucu olarak Peygamber (a.s.) çeşitli yazı malzemelerine vahyin/âyetlerin yazılması emrini vermişti. Bu anlamda şartların elverdiği bütün imkânlar kullanılmak suretiyle kâğıt, yaprak, taş, kemik, deri vs. parçalarına âyetler yazılmaya çalışılmıştı. En nihayet Hz. Peygamber vefat ettiği zaman, Kur'ân-1 Kerim'in tamamı yazıya geçirilmiş durumdaydı. ${ }^{10}$

\section{Vahyin Yazımı Ne Zaman Başladı?}

Âyetleri ve sureleri dağınık bir şekilde de olsa Kur'ân'ın tamamı Hz. Peygamber zamanında yazıya geçirilmiş durumdaydı. Peygamber (s.a.)

konusunda bir iddia söz konusu olmadığını, olsa olsa onun Yahudi ve Hıristiyan kitaplarını bilmediğinin ileri sürüldüğünü belirtir. Ayrıca Watt, Hz. Peygamber'in Mekkeli ortalama bir tacirin bildiği kadar okuma-yazma bildiğini muhtemel görmektedir. Ayrıntılar için bkz. Kur'ân'a Giriş, s. 48-52, çev. Süleyman Kalkan, Ankara 2000. F.Buhl de ümmî̀ye hem "daha evvelki semavî dinlerin mukaddes kitaplarını okuyamayan" hem de "okuma yazma bilmeyen" şeklinde anlam vermiştir. Bkz. İslâm Ansiklopedisi, VI, 998, "Kur'an" md., MEB. İstanbul, 1977. Ümmî kelimesine müșteşriklerin verdikleri anlamlarla ilgili ayrıca bkz. Yıldırım, Oryantalistlerin Yanılgıları, s. 126-131. Oryantalistlerin konuyla ilgili çalışmalarını değerlendiren Abdurrahman Bedevî ise ümmî kelimesine, Hz. Peygamber hakkında kullanıldığında "bütün milletlere gönderilmiş, uluslararası Peygamber" anlamını vermektedir. Ona göre ümmiyyûn ise "milletler, tüm milletler topluluğu" anlamındadır. Bkz. Yıldırım, age., s. 134.

8 Bkz. Hicr, 15/9.

9 Muhsin Demirci de bu görüşü destekler mahiyette, Hz. Peygamber'e gelen her Kur'ân vahyinin hıfz, kitâbet ve yıllık mukabele tarzındaki üçlü tespit işini üstü kapalı da olsa Allah Teâlâ'nın emrettiğini söyler. Bkz. Vahiy Gerçeği, s.197.

${ }^{10}$ Bkz. Suyûtî, Ebû'l-Fadl Celâlüddîn Abdurrahman b. Ebî Bekr, el-ìtkân fî ulûmi'l-Kur'ân, I, 181, I-II, Beyrut 1414/1993; Muhammed Ebû Şehbe, el-Medhal li dirâseti'l-Kur'âni'l-Kerim, s. 338, Riyad 1407/1987. 
inen her âyeti ezberliyor, sahâbeye okuyor ve onlardan da ezberleyenler oluyordu. Aynı zamanda her sene Ramazan ayında bir defa ve vefat ettikleri en son yıl iki defa olmak üzere Peygamber (s.a.) o zamana kadar gelen bütün vahiyleri Cebrail ile tekrar gözden geçiriyorlardı ki buna arza ismi verilmişti. ${ }^{11}$ İlk vahyin geldiği anlardan itibaren ezberlenen ve sürekli okunan vahiy malzemesinin hemen olmasa bile çok kısa bir süre içerisinde yazılmaya başlanmış olması gerekir. Fakat vahiy kitâbetinin tam olarak ne zaman başladığ Kur'ân âyetleri de bu konuda bize sarih bir bilgi vermez. Gelen âyetler düzensiz bir şekilde nâzil oluyor ve hangi âyetin hangi surenin neresine konulacağını Hz. Peygamber bildiriyor ve ona göre malzemelere kaydediliyordu. ${ }^{12}$ Âyetler çok erken bir zaman diliminde yazıya geçmemiş olsa, bütün bu âyetlerin karışma ihtimali ortaya çıkacaktı. Dolayısıyla ilk vahyi takip eden şaşkınlık ve hayret durumu geçer geçmez Hz. Peygamber'in bunların yazıya geçirilmesi talimatını vermiş olduğunu düşünebiliriz. Âyetlerdeki bazı işaretleri ve çeşitli rivâyetleri göz önünde bulundurarak İslâm'in ta ilk dönemlerinden itibaren Hz. Peygamber'in kendisine vahiy kâtipleri edindiğini söylememiz mümkün görünmektedir. ${ }^{13}$

${ }^{11}$ Cebrâil ile Rasûlullah arasında gerçekleşen bu arza hâdisesinin bir benzerinin sahâbe ile Peygamber (a.s.) arasında cereyan ettiği ve sahâbenin kendilerinde bulunan vahiy malzemesini hem hıfz hem de kitâbet olarak ona arzettiği yönündeki kimi ifadeler (mesela bkz. Mennâu'l-Kattân, Mebâhis fi ulûmi'l-Kur'ân, s. 119, Kahire 2000) tartışmaya açı görünmektedir. Çünkü her ne kadar Hz. Peygamber sahâbîlerin ezbere okuduğu âyetleri tashih edebilirse de yazılı olarak getirilen metinleri tashih etmesi mümkün olmasa gerek. Eğer böyle bir durum var ise, kendisi değil de yetkili vahiy kâtipleri bu metinleri kontrol ediyor olmalıdırlar. Zaten yazılan bu metinler ilk etapta yine onların bilgisi dâhilinde yazıllyor, herkes kendi bildiğine bunları yazmaya kalkmıordu.

12 Bkz. Tirmizi, Ebû Îsâ Muhammed b. Îsâ, el-Câmiu's-Sahîh (Sünenu't-Tirmizî), Tefsîru'l-Kur'ân 10, no: 3086, I-V, Beyrut, ts.; Zerkeşî, Ebû Abdillah Muhammed b. Bahâdır, el-Burhân fì ulûmi'l-Kur'ân, I, 325, I-IV, Beyrut 1410/1990; Hamidullah, Muhammed, İslâm Peygamberi (Hayatı ve Faaliyeti), II, 698, prg. 1127, I-II, İstanbul, 1414/1993, çev. Salih Tuğ.

${ }^{13}$ Bkz. Ersöz, İsmet, Kur'ân Tarihi-Kur'ân-ı Kerim'in İndirilişi ve Bugüne Gelişi, s. 75-79, İstanbul, 1996; Demirci, Muhsin, Vahiy Gerçeği, s. 222; Kaddûrî, Resmu'l-Mushaf-dirâse luğaviyye târihiyye, s. 97, yy. 1402/1982. Bu konuda DİA'da şu değerlendirmeler yapılmıștır: "Nâzil olan âyetlerin Mekke döneminin ilk yıllarından itibaren yazıldığına dair bizzat Kur'ân'da, hadis kaynaklarında ve tarih kitaplarında bilgiler bulunmaktadır. Müslümanların sayıca az olduğu ilk birkaç yılda vahyin yazdırılmamış olabileceği düşünülse bile bu bir mahzur teşkil etmemiştir. Çünkü bu dönemde inen sureler, gerek çok kısa olmaları gerekse üslup özellikleri dolayısıyla Rasûl-i Ekrem ve sahâbîler tarafından kolayca ezberlenmekte ve okunmaktaydı. Vahyin erken dönemlerden itibaren yazıldığına dair en önemli delillerden biri Hz. Ömer'in Müslüman olması hâdisesidir..." Bkz. Birışık, Abdülhamit, DİA, "Kur'an" md., XXVI, 385, Ankara 2002. 
Öğrendiğimize göre Hz. Peygamber'in Mekke'deki ilk vahiy kâtibi olarak ismi geçen kişi Abdullah b. Sa'd b. Ebî Serh'tir. ${ }^{14}$ Belâzurî (ö.279/892), onun Kureyş kabilesinden Hz. Peygambere kâtiplik yapan ilk kişi olduğunu, sonradan irtidat edip Mekke'ye döndüğünü ve Kureyş'e: "Muhammed'in getirdiğgi şeyler gibisini ben de getiriyorum!" dediğini, onun hakkında En'âm, 6/93 âyetinin indiğini kaydeder. ${ }^{15}$ İbn Kuteybe onun vahyi nasıl tahrif etmeye çalıştı̆̆ konusunda bir örnek verir ki eğer

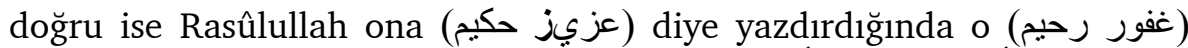

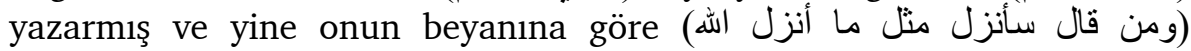
"(Allah'a karşı yalan uydurandan yahut kendisine hiçbir şey vahyedilmemişken, 'Bana da vahyolundu' diyenden) ve 'Ben de Allah'ın indirdiği (âyetlerin) benzerini indireceğim' diyenden (daha zâlim kim vardır!)" âyeti (En'âm, 6/93) onun hakkında nazil olmuştur. Bu nedenle Hz. Peygamber Mekke'nin fethi günü onun kanının heder olduğunu söylemiş, fakat sütkardeşi olan $\mathrm{Hz}$. Osman eman vererek onu kurtarmıştır. ${ }^{16} A^{\prime}$ zamî de onun birkaç âyeti uydurmakla suçlandığını ancak bu suçlamaların temelsiz olduğunu söyler. ${ }^{17}$

\section{Âyetlerdeki İsaretler}

Gelen vahiylerin yazıya geçirildiğine dair çeşitli âyetlerde işaretler mevcuttur. Sözgelimi; ilk inen 'Alak suresi oku emriyle başlar ve devamında Allah'ın kalemle (yazmayı) öğrettiği vurgulanır. ${ }^{18}$ Yine Kur'ân'ın ikinci sırada nâzil olan suresi Kalem suresidir ve bu surenin hemen başında, "kaleme ve onun yazdıklarına" yemin edilir. ${ }^{19}$ Mekke'de nâzil olan Tûr suresi de, "yayılmış ince deriler üzerine düzenle yazılmıs

\footnotetext{
${ }^{14}$ Bkz. Belâzurî, Ebû'l-Abbâs Ahmed b. Yahya, Fütûhu'l-buldân, s. 662, Beyrut 1407/1987; çevirisinden s. 693-694, prg. 1112, çev. Mustafa Fayda, Ankara 2002; İbn Hacer, Ebû'l-Fadl Ahmed b. Ali b. Hacer el-Askalânî, Fethu'l-bârî şerhu Sahîhi'l-Buhârî, IX, 22, I-XIII, Beyrut 1379; Ebû Şehbe, Medhal, s. 338.

${ }^{15}$ Belâzurî, age., s. 662; çeviriden s. 693-694, prg. 1112.

${ }^{16}$ Bkz. İbn Kuteybe, Ebû Muhammed Abdullah b. Müslim, el-Maârif, s. 300-301, Kahire, ts.. İbn Kesîr onun irtidat ettikten sonra Mekke'nin fethi günü tekrar İslâm'a döndüğünü ve bundan sonra güzel bir İslâmî yaşantısı olduğunu kaydeder. Bkz. İbn Kesîr, Ebû'l-Fidâ İsmâil b. Ömer, es-Sîretu'n-Nebeviyye, IV, 689, I-IV, Beyrut 1395/1976

${ }^{17}$ M.M. el-A'zamî, Vahyedilişsinden Derlenişine Kur'ân Tarihi- Eski ve Yeni Ahit ile Karşılaştırmalı Bir Araştırma, s. 106, trc. Ömer Türker, Fatih Serenli, İstanbul 2006.

${ }^{18}$ Bkz. 'Alak, 96/1-5.

${ }^{19}$ Bkz. Kalem, 68/1-2. Kalem (Nûn) suresi nüzul sırasına göre tertip olunmuş Hz. Osman, İbn Abbas ve Ca'fer es-Sâdık'ın mushaflarında ikinci sırada yer almaktadır. Bkz. Cerrahoğlu, Tefsir Usûlü, s. 86, Ankara 1991.
} 


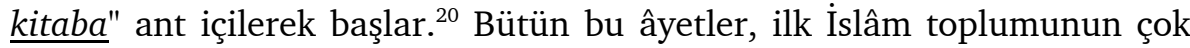
erken bir zamanda kitapla, yazıyla ve yazı malzemeleriyle tanıştı̆̆ını gösterir. Şu âyet de bunu teyit eder:

$$
\text { وقالوا أساطير الأولين اكتتبها فهي تملى عليه بكرة و أصيلا }
$$

"Onlar dediler ki: (Bu âyetler) onun, başkasina yazdırıp da kendisine sabah-akşam okunmakta olan, öncekilere ait olan masallardır." 21

Kur'ân'ın bir ismi de el-Kitâb'tır ki bu kelime "yazılmış olan/mektup" anlamına gelir. Sözlü olarak nakledilen şeylere değil yazılı olarak nakledilenlere kitap ismi verildiğini rivâyetlerden açıç̧a anlıyoruz. Mesela bunlardan birinde verilen bilgiye göre Hz. Peygamber, saçının örgüsü içinde bir kitap (/sahife, mektup) taşıyan casus bir kadını yakalatmak üzere Ali, Zübeyr ve Mikdâd'ı görevlendirmiştir. ${ }^{22}$ Şayet casus olarak gönderilen kadın yüklendiği vazifeyi yazılı değil de sözlü olarak yerine getirecek olsaydı, onda bulunan ve gizlemeye çalıştı̆̆ 1 şeye kitap denmesi mümkün olmayacaktı. Demek ki yazılı bir metin söz konusuydu. Yine Rasûlullah'ın İslâm'a davet etmek üzere devlet başkanlarına gönderdiği mektuplar için kitap ifadesi kullanılmıştır. ${ }^{23}$

Hulâsa, tek başına bu "kitap" kelimesi bile âyetlerin daha ilk baştan (Mekke döneminden) itibaren kayda geçirilmiş olduğunun bir ifadesi sayılabilir. W. Montgomery Watt da "Kitap" ile "Kur'ân" (yazma-okuma) kelimeleri arasındaki zıtlıktan hareketle, vahiylerin Hz. Muhammed'e gelmelerinden kısa bir süre sonra yazıya geçirildiğinin ima edildiğini söylemiştir. ${ }^{24}$

Bu arada Kur'ân'da geçen "sûre" kelimesinin de yazılı bir malzemeye işaret ettiği yönünde ipuçları vardır. ${ }^{25}$ Kur'ân, bir benzerinin getirilmesi konusunda inkârcılara meydan okumuş, onun benzeri bir sure bile

${ }^{20}$ Bkz. Tûr, 52/1-3. Tûr suresi Hz. Osman mushafında 76., İbn Abbas mushafında 73. ve Ca'fer es-Sâdık'ın mushafında 75. sıradadır. Bkz. Cerrahoğlu, age., s. 87.

${ }^{21}$ Furkân, 25/5.

${ }^{22}$ Bkz. Ahmed, Müsned, I, 79; Buhârî, İsti'zân 23 (no: 5904), Cihâd 139 (no: 2845), 191 (no: 2915), Meğâzî 44 (no: 4025), Tefsir 368 (no: 4608), I-VII, Beyrut, 1410/1990; Müslim, Fezâilu's-sahâbe 161.

${ }^{23}$ Mesela Rumların lideri Hirakl'e gönderilen mektupla ilgili olarak bkz. Buhârî, İsti'zân 24 (no: 5905).

${ }^{24}$ Bkz. Kur'ân'a Giriş, s. 163.

${ }^{25}$ Sure kelimesinin İbrânî dilinde "yazı satırlarına" delâlet ettiği, "yazılmış şey" manasına geldiği ve Peygamber'in de onu kabul ettiği ifade edilir. Bkz. Caetani, İslâm Tarihi, IX, 169, not: 1, trc. Hüseyin Câhid, İstanbul 1926. Ancak Lisânu'l-Arab (İbn Manzûr, XXIV, 2146-2149, "s-v-r" md., I-LV, Kahire ts.) ve Tâcu'l-arûs (Zebîdî, XII, 99-110, "s-v-r" md., I-XL, Kuveyt 1393/1973) gibi Arapça sözlüklerde sure kelimesinin bu anlama geldiğine dair bir bilgiye ulaşamadık. 
getirmekten onların âciz olduklarını vurgulamıştır. ${ }^{26}$ Isşte bu meydan okumanın, aynı zamanda Kur'ân âyetlerinin yazılı bir şekilde muhafaza edildiği konusunda delil olduğu yönünde değerlendirmeler vardır. ${ }^{27}$ Son olarak özellikle Beyyine suresinde geçen "suhuf" kelimesinin de konumuz açısından dikkatten kaçırılmaması gerektiğini düşünüyoruz. ${ }^{28}$

\section{Rivâyetlerdeki Bilgiler}

1. Vahyin çok erken bir dönemde yazıya geçirilmeye başlandığı konusunda delil olarak en çok kullanılan husus Hz. Ömer'in Müslüman olmasıyla yakından ilgilidir. Bilindiği üzere Hz. Ömer ilk Müslüman olan kişilerdendir. ${ }^{29} \mathrm{Bu}$ olayın hemen öncesinde onun, kızgın bir şekilde kızkardeşinin ve eniştesinin evine gittiği sırada, orada yazılı bir malzemeden Tâhâ suresinden bir bölüm okunduğu, Ömer'in onu duyduğu ve çok etkilendiği anlatılır. ${ }^{30}$

\footnotetext{
${ }^{26}$ Bkz. Bakara, 2/23-24.

${ }^{27}$ Mesela F. Buhl'e göre, Peygamber hasımlarına meydan okuyup, kendi surelerine benzer on sure yazmalarını istediği zaman (XI, 16 [doğrusu Hûd, 11/13 olmalı. BT.]), bu şüphesiz mukayese edilebilecek yazılı surelerin mevcut olduğunu gösterir. Bkz. "Kur'an" md., İA., VI, 1000, İstanbul 1977.

${ }^{28}$ Suhuf kelimesi "sahîfe" kelimesinin çoğulu olup, içine bir şeyler yazılan malzeme anlamına gelir. Aynı kökten türetilen "Mushaf" da, yazılı sahifeleri toplayan anlamındadır. Bkz. İsfehânî, er-Râğıb, Müfredâtu elfâzi'l-Kur'ân, s. 476, thk. Safvân Adnân Dâvudî, Beyrut 1412/1992. Bu açıdan bakıldı̆̆ında Beyyine, 98/2 âyetinde Hz. Peygamber'in "tertemiz sahifeleri okuyan bir elçi" şeklinde tavsif edilmesi oldukça manidardır. Bu âyet de Hz. Peygamber'in getirdiği vahiylerin sahifelerde yazılı olduğunu ispatlamaktadır.

${ }^{29}$ İbn İshâk onun Habeşistan'a hicretten sonra Müslüman olduğunu kaydeder. Bkz. Ebû Bekr Muhammed b. İshâk el-Muttalibî el-Medenî, Siretu İbn İshâk el-musemmât bi kitâbi'l-mubtede' ve'l-meb'as ve'l-meğâzî̀, s. 160, prg. 221, Konya 1401/1981, thk. Muhammed Hamidullah. Onun nübüvvetin 6. yılında Müslüman olduğu hakkında bkz. İbn Sa'd, Tabakât, III, 269. Hamidullah, Hz. Ömer'in İslâm'a giriş tarihinin hicretten önce 8. yıla yani Rasûlullah'ın peygamberlik görevine başlamasının 5. yılına isabet ettiğini söyler. Bkz. İslâm Peygamberi, I, 108, prg. 194. Hz. Ömer'in kırkıncı Müslüman olduğu yönündeki yaygın kanaat doğru olmasa gerek. Nitekim İbn Kesîr de, Habeşistan'a hicretten sonra Müslüman olan Hz. Ömer'in kırkıncı Müslüman olamayacağına, çünkü Habeşistan'a hicret edenlerin sayısının bile seksenin üzerinde olduğuna dikkat çekmiş; belki hicret edenlerin hariç tutulması durumunda onun kırkıncı kişi olabileceğini söylemiş̧tir. Bkz. es-Sîretu'n-Nebeviyye, II, 33. Hz. Ömer'in kaçıncı Müslüman olduğuyla ilgili olarak değerlendirmeler için bkz. Sen, Ziya, Kur'an'ın Metinleșme Sürecinde Ortaya Çıkan Problemler, s. 42-43, Doktora Tezi, Dokuz Eylül Ü. SBE., İzmir 2006.

${ }^{30}$ Mesela bkz. İbn İshâk, Sîre, s. 160-163, prg. 223; İbn Hişâm, Ebû Muhammed Abdülmelik b. Hişâm, es-Sîretu'n-Nebeviyye, I, 431-435, prg. 332, I-V, thk. Mecdi Fethi es-Seyyid, Beyrut 1416/1995; çevirisi: Siret-i İbn Hişam-Hz. Muhammed'in Hayatı, s. 116-119, çev. Arif Erkan, İstanbul 1995.
} 
$\mathrm{Bu}$ olayı kaydeden kimi rivâyette okunan âyetlerin yazılı olduğu malzemeyi anlatmak için sahife $e^{31}$ kimi rivâyette ise kitâb $b^{32}$ kelimesi kullanılmaktadır. Her iki durumda da sonuç değişmemekte ve eldeki malzemenin yazılı bir nüsha olduğu noktası açı̆̆a çıkmaktadır. Bu olayın gerçek olması durumunda vahyin ne kadar erken bir dönemde (bisetin 5 . yılından önce) yazılmaya başlandığını anlamamız kolaylaşacaktır. Ayrıca Tâhâ suresinin yazılı olduğu bu sahifenin, Müslümanların ellerinde dolaşmakta olan sahifelerden sadece birisi olduğunu düşünmemiz de mümkündür. ${ }^{33}$

Hz. Ömer'in kızkardeşinin yanında okuduğu sahife/kitap sebebiyle Müslüman olduğunu anlatan rivâyetler genellikle sahâbeden Enes $b$. Mâlik ve $H z$. Ömer'den nakledilir. Bazı rivâyetler ise sahâbeye kadar ulaşan senedi verilmeden veya kimin rivâyet ettiği kısaca söylenerek kaydedilmiştir. ${ }^{34}$

${ }^{31}$ Bkz. İbn İshâk, Sîre, s. 162, prg. 223; İbn Hişâm, Sîre, I, 433, 434; Ahmed, Fezâilu's-sahâbe, I, 280, I-II, Beyrut 1403/1983; İbn Hibbân, Ebû Hâtim Muhammed b. Hibbân el-Büstî, es-Sikât, I, 73, I-IX, yy., 1395/1975; İbn Kesîr, es-Sîretu'n-Nebeviyye, II, 34.

32 İbn Sa'd, Ebû Abdillah Muhammed el-Basrî, et-Tabakâtu'l-kebîr, III, 268, I-VIII, Beyrut ts.; Hâkim, Ebû Abdillah Muhammed b. Abdillah en-Nîsâbûrî, el-Müstedrek ale's-Sahîhayn, IV, 65 (no: 6897), I-IV, Beyrut 1411/1990; İbnu'l-Cevzî, Ebû'l-Ferec Abdurrahman b. Ali, Sifatu'ssafve, I, 270, I-IV, Beyrut 1399/1979.

${ }^{33}$ Bkz. Kaddûrî, Ğânim, Resmu'l-Mushaf, s. 97. Bu konuyu ele alan günümüz araştırmacılarından İsmet Ersöz şu değerlendirmelerde bulunmaktadır: "Demek oluyor ki Kur'ân'ın yazılmaya başlaması İslâm'ın ta ilk dönemlerinde gerçekleşmiştir. Her ne kadar bu olay vesilesiyle, Kur'ân'dan bir parçanın yazılı olduğu belgeden ilk olarak söz edilmekte ise de, bu daha önce Kur'ân'dan bir şeylerin yazılmamıs olduğunu asla ifade etmez. Kaldı ki, vahiy kâtipleri arasında ne Hz. Ömer'in kız kardeşinin ne de eniştesinin adı geçmektedir. Adları geçmediği halde onlarda Kur'ân'dan yazılı metin bulunduğuna göre, ilk Müslümanlardan olan ve adları vahiy kâtipleri arasında geçen gerek Hz. Ebû Bekir gerekse Hz. Ali'de, o zamana kadar inen âyetlerin yazılı nüshaları olabileceği niçin düşünülmesin? Evet biz, Hz. Peygamber'in vahiy kâtipleri edindiği tarihi kesin olarak bilemiyoruz. Ancak, bisetten sonraki erken dönemlerde başladığını ve zamanla tabir caizse kurumlaşı̆̆ı̆ı söyleyebiliriz." Bkz. Kur'ân Tarihi, s. 77-78. Caetani ise, Hz. Ömer'in Müslüman olmasıyla ilgili hikâyenin umumi muhtevası doğru kabul edilse bile, bu hadisin istinat ettiği râvinin tafsilatın güvenilirliği hakkında insana şüphe verdiğini; hicretten önce Peygamber'in tebliğ ettiği Kur'ân âyetlerinin yazılarak korunmasına ehemmiyet vermediğini, Medine'ye hicretten sonra âyetlerin yazdırılarak koruma altına alındığını iddia etmiştir. Bkz. Caetani, İslâm Tarihi, IX, 168, prg. 219.

${ }^{34}$ Bkz. İbn İshâk, Sîre, s. 160-163, prg. 223 (sadece Ahmed-Yunus-İbn İshâk isnâdıyla); İbn Hişâm, Sîre, I, 431, prg. 332 (sadece "İbn İshâk dedi ki" diyerek. Burada kaydedilen hadisin birçok sahâbî râvisi olması sebebiyle "hasen hadis" olduğu tahkik eden (Mecdi Fethi es-Seyyid) tarafından söylenmiştir.); Ahmed, Fezâilu's-sahâbe, I, 279, no: 371 ("beleğanî" denilerek); İbn Kesîr, es-Sîretu'n-Nebeviyye, II, 33 (İbn İshâk'tan naklen). 
Enes'ten gelen rivâyetlerin isnâdı: İshâk b. Yusuf el-Ezrak ${ }^{35}$ - el-Kâsım b. Osman el-Basrîi ${ }^{36}$ - Enes b. Mâlik şeklindedir. ${ }^{37}$ Bu isnâdın, el-Kâsım b. Osman el-Basrî sebebiyle zayıf olduğu anlaşılmaktadır. Nitekim Zehebî de onun incelemekte olduğumuz Hz. Ömer'le ilgili rivâyetini tenkit etmiştir. ${ }^{38}$

Ömer'den gelen rivâyetler ise Üsâme b. Zeyd b. Eslem ${ }^{39}$ - Zeyd b. Eslem $^{40}$ - Eslem ${ }^{41}$ - Ömer isnâdıyla nakledilir. ${ }^{42} \mathrm{~Hz}$. Ömer'den gelen tarik de özellikle Üsâme sebebiyle zayıf görünmektedir.

Müsteşrik L.Caetani de, Hz. Ömer'in Müslüman olmasıyla ilgili hikâyenin umumi muhtevası doğru kabul etmekle birlikte, bu hadisin

35 İshâk b. Yusuf b. Mirdâs el-Mahzûmî el-Vâsıtî (ö.195), "el-Ezrak" diye bilinir, sikadır. Bkz. İbn Hacer, Takrîbu't-Tehzîb, s. 133, no: 400, Riyâd 1416.

${ }^{36}$ Ebû'l-'Alâ el-Kâsım b. Osmân el-Basrî. Buhârînin onun mütâbii olmayan hadisleri bulunduğunu söylediği ifade edilir. (Zehebî, Şemsüddîn Ebû Abdillah Muhammed b. Ahmed, Mîzânu'l-i'tidâl fî nakdi'r-ricâl, V, 456, no: 6831, I-VIII, Beyrut 1995; Heysemî, Nûruddîn Ali b. Ebî Bekr, Mecmau'z-zevâid, I, 259, IX, 62, I-X, Kâhire-Beyrut 1407.) İbn Hibbân, sika râvileri topladığı meşhur eserinde ona da yer vermiş, fakat zaman zaman hata ettiğini ifade etmiştir. (Sikât, V, 307, no: 4976). Heysemî de el-Kâsım b. Osman'ın zayıf olduğu kanaatindedir. (Age., I, 259, IX, 62).

${ }^{37}$ Enes rivâyetinin bulunduğu bazı kaynaklar şöyledir: İbn Sa'd, Tabakât, III, 267; Hâkim, Müstedrek, IV, 65 (no: 6897); Beyhakî, Ebû Bekr Ahmed b. el-Huseyn, Delâilu'n-nubuvve, II, 92 (no: 519), Şâmile-2; İbnu'l-Cevzî, Sifatu's-safve, I, 269 (isnâdsız); İbn Hacer, el-Metâlibu'lâliye, XII, 158, no: 4344, Şâmile-2.

${ }^{38}$ Zehebî̀nin, el-Kâsım'ın İshâk el-Ezrak'tan mahfûz (sağlam) bir metin nakletmekle birlikte, onun naklettiği Hz. Ömer'in Müslüman olmasıyla ilgili kıssayı "cidden münker" olarak tavsif etmesi konumuz açısından oldukça dikkat çekicidir. (Mîzânu'l-i'tidâl, V, 456, no: 6831.) Bu durumda el-Kâsım b. Osman'ın zayıf olma ihtimalinin daha fazla olduğunu söyleyebiliriz.

39 Üsâme b. Zeyd b. Eslem el-Adevî el-Medenî. Buhârî hocası Ali b. el-Medînî'den naklen onun sika olduğunu ve onu hayırla yad ettiğini söyler. (et-Târîhu'l-kebîr, II, 23, no: 1561, I-VIII, ts.) Ancak İbn Sa'd'ın ifadesiyle çok hadis rivâyet eden ve huccet olmayan birisidir. (Tabakât, V, 413.) Nesâî'ye göre kavi değildir. (ed-Duafâ ve'l-metrûkîn, s. 19, no: 52, Haleb 1369.) İbn Hibbân, mecruh râvileri topladığı eserine onu da almış, rivâyetlerinde vehim ve hata bulunduğunu hatta mevkufu ref, maktu rivâyetleri de vaslettiğini belirtmiştir. (Mecrûhîn, I, 179, no: 115, I-III, Haleb ts.) İbnu'l-Cevzî'nin kaydettiğine göre de onun hakkında Ahmed b. Hanbel münkeru'l-hadis ve zayıf demiş, Yahyâ b. Saîd de hadisini terk etmiştir. (ed-Duafâ ve'tmetrûkîn, I, 95, no: 288, I-II, Beyrut 1406.) İbn Hacer onun hâfizasından dolayı zayıf olduğunu ve el-Mansûr'un halifeliği zamanında öldüğünü söyler. (Takrîb, s. 123, no: 317.)

${ }^{40}$ Ebû Usâme Zeyd b. Eslem el-Adevî el-Medenî (ö.136). İbn Hacer sika ve âlim olduğunu, mürsel rivâyette bulunduğunu ifade etmektedir. (Takrîb, s. 350, no: 2129.)

${ }^{41}$ Eslem el-Adevî (ö.80). İbn Hacer'in ifadesiyle Hz. Ömer'in kölesidir, sikadır ve muhadramdır. (Takrîb, s. 135, no: 410.)

42 Ömer rivâyetlerinin bulunduğu bazı kaynaklar: Ahmed, Fezâilu's-sahâbe, I, 288 (no: 377); Bezzâr, Ebû Bekr Ahmed b. Amr, Müsned, I, 400-403 (no: 279), I-X, Beyrut 1409; Ebû Nuaym, Ahmed b. Abdillah el-İsbehânî, Hrlyetu'l-evliyâ, I, 41 (kızkardeşinin yanına geldiğinden bahsedilmiyor), I-X, Beyrut 1405; Beyhakî, Delâilu'n-nubuvve, II, 91 (no: 518); Heysemî, Mecmau'z-zevâid, IX, 63-65. 
istinat ettiği râvinin tafsilatın güvenilirliği hakkında insana şüphe verdiğini söylemiş, ancak bu râvinin kim olduğunu beyan etmemiştir. ${ }^{43}$

Bütün bu incelemelerimiz sonucu Hz. Ömer'in kızkardeşiyle olan görüşmesinde Müslüman olduğunu bildiren rivâyetlerin isnâd açısından bazı kusurlar taşıdığı anlaşılmaktadır. Bununla birlikte rivâyetlerde genellikle birbirine benzer bir metin ortaya konulmaktadır. Dolayısıyla içerik itibariyle bu rivâyetleri görmezden gelmek veya yok saymak doğru olmasa gerektir. ${ }^{44}$

2. Hz. Peygamber'in: "Benden Kur'ân dışında hiçbir şey yazmayın! Kim benden Kur'ân dışında bir şey onu yazmışsa imha etsin." diyerek Kur'ân âyetleri dişında hiçbir şey yazılmasına izin vermediğine dair bazı rivâyetler vardır. ${ }^{45} \mathrm{Bu}$ yasak ne zaman konulmuştu, her türlü yazma işlemini ve herkesi kapsıyor muydu gibi konularda bir netlik yoktur. Kaynaklarımızdan bu yasağın umumî olmadığını, herkesi kapsamadığını, âyetlerin arasına vahiy olmayan unsurların karışma ihtimalinin ortadan kaldırılmasının ve Kur'ân'a gereken ilginin gösterilmesinin hedeflendiğini, sahâbeden yazmaya devam edenlerin olduğunu ve bunu $\mathrm{Hz}$. Peygamber'in bildiğini öğreniyoruz. ${ }^{46}$

${ }^{43}$ Bkz. Caetani, İslâm Tarihi, IX, 168, prg. 219. Söz konusu râvinin Enes rivâyetleri için el-Kâsım b. Osman el-Basrî, Ömer rivâyetleri için ise Üsâme b. Zeyd b. Eslem olması muhtemeldir.

${ }^{44} \mathrm{~Hz}$. Ömer'in Müslüman oluşuyla ilgili iki tür rivâyet olduğu; bunlardan birincisinin burada değindiğimiz rivâyet, diğerinin ise onun Kâbe'de Kur'ân okuyan Hz. Peygamber'i dinlemesi sonucu Müslümanlığı tercih ettiği yönündeki rivâyet olup, doğru olanın da bu ikincisi olduğunu savunan bir çalışma için bkz. Azimli, Mehmet, "Hz. Ömer'in Müslüman Oluşuyla İlgili Rivayete Farklı Bir Yaklaşım", İslâmiyat, VI (2003), sayı: 1, s. 173-183. Her ne kadar yazar tarafından ikinci tür rivâyetlerin daha yaygın ve doğru olduğu savunulsa da, bunun için ortaya konulan delillerin çok da ikna edici olmadığı kanaatindeyiz. Sözgelimi, onun Kureyş kabilesi içinde sefaret gibi önemli bir göreve yükselmiş Hz. Ömer'e, Hz. Peygamber'i öldürme teşebbüsünü yakıştıramamasına rağmen, geçmişte ne denli bir işkenceci olduğunu hatırlatması (bkz. agm., s. 182, son paragraf) açık bir çelişki gibi durmaktadır. Çünkü sefarete kadar yükselen birisi işkence yapabiliyorsa, cinayete de teşebbüs edebilir. Ayrıca yazarın kendi savunduğu görüşü destekleyen rivâyetleri hemen kabul ettiği ve senet/metin tahliline gerek duymadığ 1 dikkat çekmektedir. Yine de onun Hz. Ömer'in Müslüman oluşuyla ilgili meşhur olanın aksine farklı iki tür rivâyet olduğu noktasına dikkat çeken bu çalışması bizce faydadan halî değildir.

${ }^{45}$ Mesela bkz. Ahmed, Müsned, III, 12 (no: 11100, 11102), Müslim, Zühd 72 (no: 3004); İbn Ebî Dâvud, Ebû Bekr Abdullah b. Süleyman b. el-Es'as es-Sicistânî, Kitâbu'l-mesâhif, I, 148 (no: 9), I-II, Beyrut 1423/2002.

${ }^{46}$ Bkz. İbn Kuteybe, Te'vîlu muhtelifi't-hadîs, s. 286-287, Beyrut 1393/1972; Müslim, Zühd 72 (no: 3004), Muhammed Fuad Abdulbâkî'ye ait dipnot. A'zamî şu değerlendirmeyi yapar: "Kur'ân'ı yazıya aktarma ashab arasında çok yaygındı. Bu uygulamanın sahâbe arasında yaygınlığı Peygamber'i kendisinden Kur'ân dışında hiçbir şey yazılmamasını emretmeye ve "Kim benden Kur'ân dışında bir şey yazmışsa onu yok etsin" demeye zorladı. Böylece o, herhangi bir karışıklığa meydan vermemek için Kur'ânî ve Kur'ânî olmayan (mesela hadis) materyallerin 
Konuyla ilgili rivâyetler çoğunlukla sahâbeden Ebû Saîd el-Hudrîye dayanır. ${ }^{47}$ Bunun yanında Ebû Hureyre'den gelen bir rivâyet de vardır. ${ }^{48}$

Ebû Saîd'den gelen rivâyetlerin isnâdı genellikle: Hemmâm b. Yahyâ $^{49}$ - Zeyd b. Elsem ${ }^{50}$ - Atâ b. Yesâr ${ }^{51}$ - Ebû Saîd el-Hudrî şeklindedir. Bu isnâdı oluşturan râvilerin durumunda dikkat çekici bir zayıflık görünmemektedir. Dolayısıyla isnâdın sağlam olduğunu söyleyebiliriz.

Kur'ân dışındaki şeylerin yazımının yasaklanmış olması, Kur'ân'ın yazılmasının yasaklanmadığını, tam tersine Kur'ân'ın yazıldığını, yazılmaya devam ettiğini gösterir. Çünkü şayet Kur'ân âyetleri yazılmıyor olsaydı, Hz. Peygamber'in bu sözü söylemesinin bir anlamı kalmazdı. Bir şeyler yazılıyordu ki, bunların arasına başka şeylerin karıştırılmasına müsaade edilmiyordu diye düşünmemiz icap eder. Gelen âyetlerin sadece hafızada tutulduğunu ve kayda geçirilmediğini düşündüğümüzde, bu takdirde hafızada tutulan şeylerin arasına, diğer yazılan şeylerin nasıl karışacağına, bunun yazılı malzeme açısından nasıl bir tehlike arzedeceğine bir anlam vermemiz mümkün görünmemektedir. Yazılı olarak muhafaza edilen âyetler için ise böyle bir karışma tehlikesini anlamamız mümkündür. Dolayısıyla Kur'ân kitâbetinin çok erken

aynı yapraklara yazılmamasını amaçlamıştı. Aslında yazamayanlar çoğunlukla mescide gelip ellerinde tirşe ve sayfalarla gönüllü kâtipler arıyorlardı." Bkz. Kur'ân Tarihi, s. 107-108.

${ }^{47}$ Ebû Saîd rivâyetlerinin bulunduğu bazı kaynaklar şunlardır: Ahmed, Müsned, III, 12 (no: 11100, 11102), 21 (no: 11174), 39 (no: 11362), 56 (no: 11553); Dârimî, Ebû Muhammed Abdullah b. Abdirrahman, Sünen, I, 130 (no: 450), I-II, Beyrut 1407; Müslim, Zühd 72 (no: 3004); İbn Kuteybe, Te'vîl, s. 286-287; Nesâî, es-Sünenu'l-kubrâ, V, 10 (no: 8008); Ebû Ya'lâ, Ahmed b. Ali el-Musennâ el-Mevsılî, Müsned, II, 466 (no: 1288), I-XIII, Dimeşk, 1404/1984; İbn Ebî Dâvud, Mesâhif, I, 148 (no: 9); İbn Hibbân, Sahîh, I, 265 (no: 64); Beyhakî, el-Medhal ilâ's-Süneni'l-kubrâ, s. 405, Kuveyt 1404; Hâkim, Müstedrek, I, 216 (no: 437); Heysemî, Mecmau'z-zevâid, I, 150-151.

${ }^{48}$ Bkz. Heysemî, age., I, 150-151 (İsnâdsız bir şekilde. Heysemî, Bezzâr'ın rivâyet ettiği bu rivâyetin isnâdında bulunan Abdurrahman b. Zeyd b. Eslem'in zayıf olduğunu belirtiyor. Bezzâr'ın Müsned'inde bu rivâyete ulaşamadık.).

${ }^{49}$ Hemmâm b. Yahyâ b. Dînâr el-Basrî (ö.163). Ebû Hâtim'e göre sika ve sadûktur, ancak hafızası biraz zayıftır; Ebû Zur'a ise onda beis olmadığı kanaatindedir. (İbn Ebî Hâtim, Ebû Muhammed Abdurrahman b. Muhammed er-Râzî el-Cerh ve't-Ta'dîl, IX, 108, I-IX, Beyrut 1271/1952.) İbn Adiyy de onun rivâyet ettiği hadislerin çoğunun müstakîm (sağlam) olduğunu söyler. (Ebû Ahmed Abdullah b. Adî el-Cürcânî, el-Kâmil fî duafâi'r-ricâl, VII, 130, IVII, Beyrut, 1409/1988.)

${ }^{50}$ Ebû Usâme Zeyd b. Eslem el-Adevî el-Medenî (ö.136). İbn Hacer sika ve âlim olduğunu, mürsel rivâyette bulunduğunu ifade etmektedir. (Takrîb, s. 350, no: 2129.)

${ }^{51}$ Ebû Muhammed Atâ b. Yesâr el-Hilâlî, Hz. Peygamber'in eşi Meymûne'nin kölesi olup Ebû Hureyre, Ebû Saîd, İbn Abbas, İbn Ömer gibi pek çok sahâbîden hadis dinlediği bildirilir. (Müslim, el-Kunâ ve'l-esmâ, I, 720 (no: 2890), I-II, Medîne 1404; İbn Hacer, Tehzîbu't-Tehzîb, VII, 194, I-XIV, Beyrut 1404/1984.) Ebû Hâtim ve Ebû Zur'a sika olduğunu söylemiştir. (İbn Ebî Hâtim, el-Cerh ve't-Ta'dîl, VI, 338.) 
başladığını söylememiz gerekir. Çünkü Kur'ân dışındaki şeyler hakkındaki yazım yasağı Mekke döneminde, vahyin ilk geldiği ve daha İslâm toplumunun vahiy olan sözlerle vahiy olmayanları birbirinden ayırma

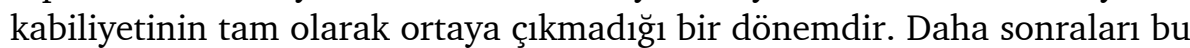
yasağın ortadan kalkması/kaldırılması da artık bu konuda endișe edilecek bir durum olmadığını, âyetlerle başka sözlerin karışma ihtimalinin ortadan kalktı̆̆ını gösterir.

3. Rasûlullah'ın, Râfi b. Mâlik el-Ensârît ${ }^{52}$ ile Akabe'de karşılaştı̆̆ı̆ında, geçen on sene boyunca nâzil olan âyetleri ona verdiği; onun da Medine'ye döndüğünde kabilesini toplayıp onlara bu âyetleri okuduğu bildirilir. ${ }^{53} \mathrm{Bu}$ olayın doğru olması durumunda, Akabe bey'atlarından bahsedilmesi sebebiyle Mekke'de cereyan etmiş olması gerekir. Buradaki anlatımda Râfi'in âyetleri hâfızasından okuduğuna dair bir kayıt yoktur; dolayısıyla onun elinde mevcut bir sahifeden söz edilmekte olduğunu anlıyoruz.

4. Sahâbe-i kiram, düşman topraklarına sefere çıtıklarında beraberlerinde Kur'ân nüshaları taşımaları, onların düşman eline geçmesini önlemek amacıyla Hz. Peygamber tarafından yasaklanmıştı. Mesela sahâbeden Abdullah b. Ömer'den nakledildiğine göre $\mathrm{Hz}$. Peygamber düşman topraklarına Kur'ân ile yolculuk etmekten menetmiştir. ${ }^{54}$ Kaynaklarımızda oldukça yaygın olan bu anlamdaki rivâyetlerden, sahâbenin ellerinde yazılı Kur'ân metinleri olduğunu açıkça anlıyoruz. Çünkü bu rivâyetteki "Kur'ân ile yolculuk" ifadesini, "yazılı Kur'ân metinleri" olarak anlamazsak, hafizalarda tutulan Kur'ân ile yolculuk yapılmasının yasaklandığı gibi anlamsız bir durum ortaya çıkar. Buhârî, Müslim, Ebû Dâvud gibi önemli müelliflerin bu rivâyeti

\footnotetext{
${ }^{52}$ Râfi' b. Mâlik b. el-Aclân el-Ensârî ez-Zurakî, Hz. Peygamber'le birlikte Akabe bey'atına katılan sahâbeden birisidir. Bkz. İbn Hacer, İsâbe, II, 444, I-VIII, Beyrut 1412/1992.

${ }^{53} \mathrm{Bu}$ olayın ayrıntıları hakkında çok fazla bilgiye sahip değiliz. Rivâyet hakkında bkz. İbn Hacer, İsâbe, II, 444; Semhûdî, Nûruddîn Ali b. Ebî'l-Hasen Abdillah eş-Şâfiî, Vefâu'l-vefâ, III, 857, Beyrut 1393/1971; A'zamî, Kur'ân Tarihi, s. 106.

${ }^{54}$ Mesela bkz. Rabî, İbn Habîb b. Ömer el-Ezdî el-Basrî, el-Câmiu's-sahîh (Müsned), s. 27, no: 12 (Ebû Saîd el-Hudrî'den), Beyrut 1415; Mâlik, Ebû Abdillah Mâlik b. Enes, el-Muvattâ, Yahyâ b. Yahyâ nüshas1, Cihâd 979 (Mâlik-Nâfi-İbn Ömer), Beyrut, 1411/1990; İbn Ebî Şeybe, Musannef, VII, 278, no: 36064; Abdurrezzak, Ebû Bekr Abdurrezzak b. Hemmâm es-San'ânî, Musannef, V, 212, no: 9410, I-XI, Beyrut, 1403; Ahmed, Müsned, II, 7, no: 4525 (Mâlik-Nâfiİbn Ömer); Buhârî, Cihâd 127, no: 2828 (Mâlik-Nâfi-İbn Ömer); Müslim, İmâre 92 (MâlikNâfi-i̇bn Ömer), 93, 94; Ebû Dâvud, Süleyman b. el-Eş'as es-Sicistânî, Sünenu Ebî Dâvûd, Cihâd 88, no: 2610 (Mâlik-Nâfi-ïbn Ömer), I-III, Beyrut, 1409/1988. Pek çok kaynakta MâlikNâfi- İbn Ömer isnâdıyla gelen bu rivâyetlerin sened olarak burada incelenmesine gerek duymuyoruz. Gerçekten sağlam görünen bu isnâd Buhârî̀ye göre "esahhu'l-esânîd" (isnâdların en sahihi) olarak kabul edilmiştir. Bkz. Naim, Ahmed, Sahîh-i Buhârî Muhtasarı Tecrîd-i Sarîh Tercemesi, I, 211, I-XIII, Ankara 1987.
} 
naklettikleri bab başlıklarında "mushaf/mesâhif" gibi ifadeler kullanmaları da yazılı bir metinden söz edildiğini gösterir. Ayrıca bazı rivâyetlerde "düşmanın eline geçmesinden korkulduğu" şeklinde bir endişe de dile getirilmektedir. ${ }^{55}$ Yazılı olmayan ve sadece hafizada saklanan şeylerin başkalarının eline geçmesi mümkün değildir. Bu da açıçca daha Hz. Peygamber hayattayken Kur'ân'ın yazıldığının ve insanlarda bu yazılı malzemelerin yaygın olarak bulunduğunun bir başka göstergesidir.

Mekke döneminde düşmana karşı sefere izin verilmediği düşünülürse, burada söz konusu edilen seferlerin Hz. Peygamber'in ömrünün Medîne döneminde olduğu anlaşılır; çünkü savaş âyetleri bu dönemde nâzil olmuştur.

5. İbn Abbas'a isnâd edilen bir görüşten, Mekke'de nâzil olan âyetlerin Mekke'de, Medîne'de nâzil olan âyetlerin Medîne'de kaydedildiğini; Fâtiha suresinin Mekke'de nâzil olduğu zaman Mekke'de yazıldığını anlıyoruz. ${ }^{56}$ Zührînnin (ö.124/742) de aynı kanaatte olduğu söyleniyor. ${ }^{57}$ Aynı kanaati paylaşan İbn Kesîr (ö.774/1372) de, Mekke'de gelen sureleri sahâbenin yine Mekke'de yazdıklarını belirtir. ${ }^{58}$

6. Neml suresinin âyetlerinden biri olan besmelenin, Mekke'de ilk inen surelerden Fâtiha suresinin ${ }^{59}$ de bir âyeti olup olmadığı öteden beri tartışıla gelir. Vahiy kâtipleri arasında ismi geçen Hâlid b. Saîd b. el-Âs'ın,

\footnotetext{
${ }^{55}$ Mesela bkz. Rabî', Müsned, s. 27, no: 12; Mâlik, Muvattâ, Cihâd 979; Müslim, İmâre 94.

${ }^{56}$ Muhammed b. ed-Dureys'in kitabında Muhammed b. Abdillah b. Ebî Ca'fer er-Râzî- Ömer b. Hârun- Ömer b. Atâ- babası- İbn Abbas isnâdıyla yer alan bu rivâyetin erken dönem kaynaklarımızda pek yaygın olmadığı göze çarpmaktadır. Bkz. İbn Dureys, Fadâilu'l-Kur'an, s. 21, no: 17, ts. yy., Şâmile-2; İbn Kesir, el-Bidaye ve'n-nihâye, V, 340 (Fâtiha'dan bahis yoktur), I-XIV, Beyrut ts.; A'zamî, Kur'ân Tarihi, s. 106.

${ }^{57}$ Bkz. Zühri, İbn Şihâb, Tenzîlu'l-Kur'an, s. 32 (Ebû Abdirrahman Muhammed b. el-Huseyn esSülemî rivâyeti), ts., yy., Şâmile-2; A'zamî, Kur'ân Tarihi, s. 106.

58 İbn Kesîr, Ebû Bekr b. Ebî Şeybe'nin: "Hz. Peygamber'in huzurunda ilk vahiy yazan kişi Übeyy b. Ka'b'dır" sözünü, Medîne'de ilk yazan odur şeklinde anlaşılmasını gerektiğini, çünkü Mekkî surelerin inzâli sırasında Übeyy'in hazır bulunmadığını, Mekke'de gelen sureleri sahâbenin yine Mekke'de yazdıklarını ifade eder. (es-Sîretu'n-Nebeviyye, IV, 669.) Rasûlullah'ın huzurunda vahyi ilk yazan kişinin Übeyy olduğu yönündeki görüș, ilerleyen sayfalarda bir de İbn Ebî Hayseme'ye isnâd edilerek verilmiştir. (IV, 671.) İbn Ebî Şeybe ismi İbn Kesîr'in diğer bir eserinde de geçmektedir. (el-Bidâye ve'n-nihâye, V, 340.) Sâlihî ise, İbn Ebî Şeybe ve İbn Ebî Hayseme dedi ki, diyerek bu görüşü her ikisine birden isnâd eder. (Sübülü'l-hudâ ve'rreşâd, XI, 375, I-XII, ts.,yy., Şâmile-2.) Bu arada "İbn Ebî Şeybe" (ابن أبي شيبة) ile "İbn Ebî Hayseme" (ابن أبي خيثمة) isimlerinin yazımı birbirine benzediği için bu iki ismin karıştırılmış olabileceği de akla gelmektedir.

${ }^{59}$ Fâtiha suresi Hz. Osman'ın mushafında 5., İbn Abbas'ın mushafında ise 6. sıradadır. Bkz. Cerrahoğlu, age., s. 86.
} 
besmeleyi yazan ilk kişi olduğu iddia edilmiştir. ${ }^{60}$ Eğer bu doğruysa, Mekke'de iken besmelenin yazılmış olması, Fâtiha'nın da yazılmış olduğu sonucunu doğuracaktır. Dolayısıyla bu da, âyetlerin Mekke'de yazıya geçirildiği konusunda diğer rivâyetleri teyit eder.

\section{Rivâyetlerin Ortaya Koyduğu Sonuç}

Buraya kadarki incelemelerimizde ortaya çımıştır ki, Hz. Peygamber inişinden hemen sonra vahyin yazılmasına ve çeşitli malzemelerde muhafaza edilmesine son derece itina göstermiştir. ${ }^{61}$ İlgili rivâyetler Kur'ân'ın Rasûlullah'ın hayatında iken, hatta daha Mekke döneminde yazıya geçirilmeye başlandığ 1 konusunda âyetlerin işaret ettiği manayı teyit etmektedir. Kur'ân âyetleri ile bu rivâyetler bir arada düşünüldüğü zaman, vahyin asr-1 saadette yazılmış olduğu noktasında bir şüphenin yersiz olduğu kanaatindeyiz.

M.M. el-A'zamî de vahyin çok erken yazılmaya başladığını belirterek; gerçekte âyetlerin İslâm'ın ilk evrelerinden itibaren hatta Müslümanlar Kureyş'in zulmü altında sayısız sıkıntılar içinde yeni filizlenen bir toplulukken bile kayda geçirildiğini söyler. ${ }^{62}$

Muhammed Hamidullah da aynı kanaattedir. Onun ifadesiyle, her hâlükârda bugün elimiz altında bulunan Kur'ân metni, ta işin başından beri sadece onu baştan sona ezberlemiş olan kimselerin hafızlarına değil fakat ayn zamanda yazılı metinlere de dayandırılmaktadır. ${ }^{63}$ Hamidullah, Kur'ân-1 Kerim'in, Medîne'ye hicret edilmeden önce bile yazıyla tespit edilmeye başlandığını; fakat Hz. Peygamber'in, almakta olduğu âyetleri

${ }^{60}$ Hâlid b. Saîd'in kızı Ümmü Hâlid'in, (أبي أول من كتب بسم اله الرحمن الرحيم) Babam besmeleyi ilk yazandı" dediği rivâyet edilir. (Bkz. İbn Ebî Dâvud, el-Ba's, s. 11, no: 10, ts., yy., Şâmile-2; Suyûtî, ed-Dürru'l-mensur I, 33, I-VI, Beyrut 1411/1990.) Suyûtî'nin kitabının bu baskısında "innî" (ben ilk yazanım) şeklinde kaydedilen bu ibaredeki ilk kelime (أبي) aynı kitabın diğer bir baskısında (I, 52, I-XVI, Kahire 1424/2003, thk. Abdullah b. Abdülmuhsin et-Türkî) "ebî" (babam ilk yazandı) şeklinde kaydedilmiştir. Farklı nüshalar farklı okumalara sebep olmuş olabilir. Kaynaklarda da "ebî" şeklindeki yazım daha yaygındır. Mesela bkz. Fâkihî, Muhammed b. İshâk, Ahbâru Mekke, III, 235, I-VI, Beyrut 1414; İbn Abdilberr, Ebû Ömer Yusuf b. Abdillah, et-Temhîd, I, 94, I-XXIV, Mağrib 1387; İbn Hacer, İsâbe, I, 278. (İbn Hacer burada İbn Ebî Dâvud Mesâhif te rivâyet etti demekteyse de bu bir zuhul olsa gerektir. Çünkü görebildiğimiz kadarıyla İbn Ebî Dâvud bu rivâyeti Kitâbu'l-mesâhifte değil, değindiğimiz gibi el-Ba's'de nakletmiş̧ir.)

${ }^{61}$ Bkz. Zakzuk, Hamdi, Oryantalizm veya Medeniyet Hesaplaşmasının Arka Plânı, s. 84, trc. Abdülaziz Hatip, İzmir 1993.

${ }^{62}$ A'zamî, Kur'ân Tarihi, s. 105. Müellif burada, Ömer b. el-Hattab'n ihtidasının hemen öncesinden bahseden hikâyenin bu noktayı açıklamakta yardımcı olacağını söyler.

${ }^{63}$ Hamidullah, İslâm Peygamberi, II, 706, prg. 1132. 
hangi tarihten itibaren yazıyla tespit ettirmeye başladığının kesin olarak bilinmediğini söyleyerek, yazıyla tespit hususunda risâletin 5. yılından (yani hicretten evvel 8. yıl) bahsedildiğine işaret eder. ${ }^{64}$

\section{Bazı Müsteşriklerin Görüşleri}

İslâm dünyasında Kur'ân'ın çok erken tarihlerde yazılmaya başlandığı konusunda genellikle bir fikir ayrılığı olmasa da bazı müsteşriklerin konuya şüpheyle bakmaya gayret ettikleri de dikkatten kaçmamaktadır. A'zamî'nin ifadesiyle oryantalistler, Kur'ân metnine saldırmak için onun yazılışını ve cem'ini soruşturarak şüphe oluşturacak bir kapı aralamaya çalışmışlardır. ${ }^{65}$

Müsteşriklerin hepsinin konuya bakışı aynı olmamakla birlikte, burada zikredeceğimiz isimler Kur'ân'ın Hz. Peygamber'in sağlığında yazılmış olduğunu itiraf etmişlerdir. Ancak bunlardan bazısı Kur'ân'ın Mekke'de değil Medîne'de yazıldığını iddia ederken, bir kısmı da Medîne'ye hicretten önce de yazıldığını kabul etmek durumunda kalmıştır.

Regis Blachere, Rasûlullah'in Medine'ye hicretinden evvel Mekke döneminde Kur'ân'ın yazılmış olmasını kabul etmez. Ona göre Kur'ân'ın yazılmasının başlangıcı Peygamber'in Medine'ye hicretinden sonra zaruri olmuş ve o Müslümanlara farz kılmaksızın bu teşebbüsü uygun görmüştür. ${ }^{66}$

\footnotetext{
${ }^{64}$ Hamidullah, Kur'ânı Kerîm Tarihi, s. 41-42, prg. 80, çev. Salih Tŭ̆, İstanbul 1993. Müellifin konuyla ilgili diğer ifadeleri şöyledir: "Nakledildiğine göre Hz. Ömer'in kız kardeșinin elinde bulunan ve kronolojik sırada 54. olarak duran 20. surenin yazılı bir nüshası Hz. Ömer'in İslâm'a girmesine vesile olmuş bulunmaktadır. İlk Sîret eserlerinden birini meydana getirmiş olan İbn İshâk bu vakayı, onun İslâm'a girmesine vesile olan ve içinde yazılı bir Kur'ân suresinin mevzu bahis olmadığı diğer bir anlatım ile birlikte kitabına almıssa da bunlardan hangisinin tercihe değer olduğuna dair herhangi bir bilgi vermemektedir. Fakat ilk vaka diğer bazı kaynaklar tarafından da nakledilmiştir (mes: Suheylî) ki bu anlatımlarda, mezkûr surenin üzerine yazılı olduğu sahife üzerinde en az bir sure daha mevcut olduğu açıklanmaktadır (7. kronolojik sıradaki 81. sure). Şurasını hatırdan çıkarmayalım ki en başta inen vahiy (K.96/15), konu olarak beșerî ilimlerin tanınıp bilinmesinde bir vasıta olan "kalem"in medh ü senasına hasredilmiştir. İşte Hz. Peygamber'in, Kur'ân'ın yazıyla tespit edilip muhafazasındaki gayreti ve titizliği buradan gelir. Ve gerçekten de 80. sure (iniş sırasında 24. sure)'nin 11-16. âyetlerinde, Kur'ân-1 Kerim'in o sırada mevcut çok sayıdaki yazılı metinlerinden (nüshalarından) bahsedilmektedir."

${ }^{65}$ Bkz. A'zamî, Kur'ân Tarihi, s. 370.

${ }^{66}$ Bkz. Sönmezsoy, Selahattin, Kur'ân ve Oryantalistler, s. 177, Fecr Yayınevi, ts., yy.; Zakzuk, Oryantalizm, s. 84-85. Blachere, Peygamber'in yazılı olarak vahiyleri tespit etme fikrini Yahudi ve Hıristiyanlardan görüp almış olduğunu iddia etmiştir. Bkz. Cerrahoğlu, Tefsir Usûlü, s. 64.
} 
L.Caetani'nin konuya bakışı da aynı istikamettedir; o diyor ki: "Kur'ân'ın nüzulü devresi hemen hemen rub' asrı işgal eder. Fakat gariptir ki hicretten evvel tebliğ ettiği âyât-ı Kur'âniyye'nin tahrîran (yazdırılarak) hıfz edilmesine Muhammed'in ehemmiyet verdiğine dair hiçbir işaret mevcut değildir. Kur'ân'ın yazılmış bir şekline dair yegâne rivâyete Ömer'in ihtidasına dair olan hadiste tesadüf edilir. Fakat hikâyenin muhteviyat-1 umumiyesi doğru diye kabul edilse bile bu hadisin istinat ettiği râvî, tafsilatın mevsûkiyeti hakkında insana şüphe veriyor. Filhakika, şâyân-1 dikkattir ki iki rivâyetten birinde yazılmış bir Kur'ân fikrasından bahis yoktur. Bunun için Medine'ye hicretten evvel Muhammed'in teblĭğ ettiği âyetleri tahrîran zapt ettirmeyi düşünmediğine, metn-i kutsînin muhafazası için kendisinin ve ashâbın hafızalarına güvendiğine hükmolunabilir."67 Caetani'ye göre $\mathrm{Hz}$. Peygamber ancak Medîne'ye hicretten sonra vahyin yazımının lüzumunu anlamıștır. $^{68}$

Arthur Jeffery, gelen vahiylerin Peygamber tarafindan hemen yazdırıldığına ve her yıl Cebrail ile karşılıklı olarak gözden geçirildiğine, onun vefat etmesinden sonra da Ebû Bekir ve Osman tarafindan cemedilip çoğaltıldığına dair olan ve kendisinin Sünnî İslâm teorisi olarak nitelendirdiği görüşü büyük ölçüde uydurma olmakla itham etmiştir. ${ }^{69}$ Bununla birlikte Jeffery batıdaki bir çalışmaya atıfta bulunarak, bir kısmı gözden geçirilmiş, bir kısmı da henüz gözden geçirilmemiş şekillerde bulunan önemli miktardaki vahiy malzemesinin Peygamber'in himayesi altında bulunduğunu ve bu malzemenin o ölmeden önce ümmetine bırakmayı arzu ettiği Kitab'ın temeli olduğunu fakat bu işi

${ }^{67}$ Caetani, İslâm Tarihi, IX, 168, prg. 219. Fakat Caetani, Mekke'de nâzil olan iki âyet hakkında bazı değerlendirmelerde bulunurken şunu söylemiștir: "Buna nazaran şu hükmü veriyoruz: Bu iki âyetin Mekkî oldukları muhakkak ise Muhammed Medine'ye hicret etmeden de Kur'ân'ın bir kısmını tahrîran zapt ettirmeye başlamıştır. Mamafih, sair hadisler bu bapta bir şey bildirmiyorlar." Bkz. İslâm Tarihi, IX, 169, not 1.

68 O şöyle diyor: "Yeni âyetleri ashâbın zihnine sokmak meselesini amelî surette nasıl hallettiğine dair hiçbir şey bilmiyoruz. Herhalde vahyedilen muhtelif fikraların o kadar sâdık ve sarih surette hıfz edildiğini görmek insana hayretler verir. Çünkü en eski âyetlerde kadim üslup sonraki tesirat ile hiç bozulmamış, tâdil edilmemiştir. Mamafih, görülüyor ki Muhammed Medine'ye hicret ettiği ve meşâgili çoğaldığ 1 , îcâbât-1 ahvâl yeni vahiylere lüzum gösterdiği zaman nâzil olan âyetleri tahrîran zapt etmenin fâide-i azimesini derk etmiş olacaktır." Bkz. İslâm Tarihi, IX, 168-169, prg. 219.

${ }^{69}$ Bkz. Jeffery, Materials for the History of the Text of the Quran (İbn Ebî Dâvud'un Kitâbu'lmesâhifine yazdı̆̆ı önsöz), s. 4-5, Leiden, E.J.Brill 1937. Jeffery'nin Kur'ân-1 Kerîm'in metinleşme tarihi ile ilgili görüşlerinin ayrıntısı için bkz. Okumuş, Mesut, "Jeffery ve Kur'an Çalışmalarındaki Yeri", Oryantalistlerin Gözüyle İslâm, s. 77-134, Editör: Ahmet Yücel, İstanbul 2003. 
gerçekleştiremeden ölümün onu yakaladığını söylemektedir. ${ }^{70}$ Yine ona göre bazı vahiy parçalarının kalıcı bir şekilde yazıya geçirilmesine bizzat Peygamber sebep olmuştur. ${ }^{71}$

T.Nöldeke ise, miladi 622 yılından evvel bile Kur'ân'ın yazılmış kısımları olduğunu kabul etmiştir. ${ }^{72}$ Harald Motzki de Nöldeke'nin Müslümanların standart Kur'ân tarihi izahını benimsediğini söyler. ${ }^{73}$

F.Schwally, Kur'ân'ın Hz. Muhammed'in yaşamı boyunca parça parça olarak yazıldığını sanmak için iyi neden vardır der. ${ }^{74}$

F.Buhl de, vahiyleri yazarak muhafazasını emniyet altına alma ihtiyacı hissedilmeden önce çok zaman geçmiş olamayacağını; bunun için temini en kolay maddeler kullanılmış olduğunu anlamanın güç olmadığını söylemiştir. ${ }^{75}$ Buhl'e göre, Peygamber tarafından yazdırılmış metinler, hususi notlar ve halkın ezberindekiler Kur'ân metninin ilk esasını teşkil etmiştir. $^{76}$

${ }^{70}$ Bkz. Jeffery, Materials, s. 5; Okumuş, Oryantalistlerin Gözüyle İslâm, s. 119. Jeffery'nin atıfta bulunduğu çalışma Edinburgh Üniversitesi'nden Dr. Bell ve Yale'den Prof. Torrey tarafından yapılmış olup, çalışmayla ilgili çok fazla ayrıntı verilmemiştir.

${ }^{71}$ Bkz. Jeffery, Materials, s. 6. Değerli ilim adamı İsmail Cerrahoğlu, Arthur Jeffery'nin, İbn Ebî Dâvud'un Kitâbu'l-mesâhif adlı eserinin mukaddimesinde Peygamber'in sağlığında Kur'ân'ın yazılı olmadığını iddia ederek, şayet yazılı olsaydı Ebû Bekir'in hilâfeti sırasında Yemâme muharebelerinde pek çok Kur'ân hâfızının şehit olması üzerine Ömer'in telaşa düşmesine gerek olmadığını, yazılı durumda olmadığı için bu endişeyi taşıdığını savunduğunu ifade etmektedir. (Tefsir Usûlü, s. 64.) Fakat Jeffery'nin Cerrahoğlu'nun gösterdiği kaynaktaki ifadelerine baktığımızda böyle bir anlam çıkarmak mümkün görünmemektedir.

72 Bkz. İslam Ansiklopedisi, I, 500, İstanbul 1942.

${ }^{73}$ Bkz. Motzki, Harald, "Kur'ân'ın Cem'i- Son Dönem Metodolojik Gelişmeler Işı̆̆ıında Batılı Görüşlere İlişkin Yeni Bir Değerlendirme", s. 136, çev. Selim Türcan, Hitit Ü. İlâhiyat Fakültesi Dergisi, 2006/2, c.V, sayı:10, ss.131-163.

${ }^{74}$ Schwally bu görüşünü, Peygamber'in vefatından kısa bir süre sonra ilk halife Ebû Bekir adına cemedilmiş bir Kur'ân bulunduğuna ilişkin rivâyetin tarihsel güvenilirliğini kendince reddederken ifade eder. O, Kur'ân'ın cem'i ile Yemâme savaşında Kur'ân uzmanlarının ağır kaybı arasında kurulan bağın kendine göre düzmece olduğunu ispatlama gayretindeyken, bunun delillerinden biri olarak da, Kur'ân'ın zaten Hz. Muhammed'in hayatı boyunca yazılmış olduğunu hatırlatmış; dolayısıyla Kur'ân'ı ezbere bilen insanların ölmesinin, onun cemedilmesi kararının alınmasının sebebi olamayacağını söylemiştir. Bkz. Motzki, "Kur'ân'ın Cem'ï", s. 137.

${ }^{75}$ Bkz. Buhl, F., "Kur'an" md., İA., VI, 1000, İstanbul 1977.

${ }^{76}$ Buhl, İA., VI, 1000-1001. Buhl konuyla ilgili şu ifadeleri de kullanır: "...Peygamber hasımlarına meydan okuyup, kendi surelerine benzer on sure yazmalarını istediği zaman (XI, 16 [13 olsa gerek BT.]), bu şüphesiz mukayese edilebilecek yazılı surelerin mevcut olduğunu gösterir. Bunu daha açık surette ispat eden bir delil de, yukarıda zikredildiği gibi, önce gelen bazı âyetlerin nesh ve ilga edilmesidir; bu âyetler yalnız şifahi olarak nakledilmiş olsa idi, bu nesih keyfiyeti zaruri olmazdı. Ömer'in İslâmiyet'i nasıl kabul ettiği hakkındaki rivâyette yazı ile doldurulmuş bir kâğıt yaprağı bahis mevzuu oluyor; fakat ananelerdeki bu gibi teferruata fazla ehemmiyet atfetmemelidir. Peygamber, Medine'nin hâkimi olarak taraftarlarının 
Kur'ân'ın yazılması ve toplanması konusunda müsteşrikler tarafından ortaya konulan şüpheler konusunda Zerkânî kapsamlı bir reddiye yazmıştır. ${ }^{77}$

\section{Kitâbet mi Önce, Tebliğ mi?}

Hz. Peygamber'in Kur'ân âyetlerini hem yazdırdı̆̆ 1 hem de insanlara teblĭ̆ edip öğrettiği bilinmektedir. Peki, acaba bunlardan hangisi daha önceydi?

İbn İshâk'ın (ö.151/768) beyanına göre Peygamber (s.a.), Kur'ân nazil olduğu zaman onu ilk önce erkeklere sonra da kadınlara okumuştur. $^{78} \mathrm{Bu}$ rivâyette sadece insanlara tebliğgden bahsedilmesi ve kitâbetten söz edilmemiş olması, sanki tebliğin kitâbetten daha önce olduğunu ifade eder gibidir. Acaba bu genel geçer bir durum mudur yani her zaman mutlaka böyle mi olurdu, bu konuda açıklı yoktur. Muhammed Hamidullah, İbn İshâk'tan naklettiği bu bilginin peşinden şu ifadeleri kullanır:

"...ancak bundan sonradır ki yazıcılardan birini çağırıyor ve ona kendisine vahyedilmiş olan âyetleri kaydettirip yazı ile tespit ettiriyordu. Kâtip yazı işini bitirince, Rasûlullah ona, yazdığı âyet metnini yüksek sesle okumasını emrediyor ve böylece şayet vahiy kâtibi yanlış veya eksik veya ziyade yazmışsa düzeltme imkânı hâsıl oluyordu."79

Hamidullah'ın bu ifadelerinden, kitâbetin tebliğden sonra olduğu açıkça anlaşılmakta ise de, onun bu sözlerin hemen akabinde yer alan şu anlatımı, sanki kitâbetin sonra değil önce olduğunu ortaya koyar mahiyettedir:

"Zeyd b. Sâbit adındaki kâtiplerden biri bize onun şu metodunu açıklamaktadır: Rasûlullah bana yazdırıyor ve bitirince de yazdı̆̆ım âyeti yine bana okutturuyordu. Şayet bir yanlış veya noksan bulursa bunu düzelttiriyordu. İşte bundan sonradır ki ben kalkıp bu (âyeti) insanlara bildiriyordum." 80

birçoklarına pek fazla yazılar yazdırdı; bunların çoğu kâtibinin ismi ile zamanımıza kadar muhafaza edilmiştir..." Bkz. İA., VI, 1000.

${ }^{77}$ Bkz. Menâhil, I, 216-234.

${ }^{78}$ Bkz. İbn İshâk, Siyer, s. 203, prg. 192.

${ }^{79}$ Hamidullah, İslâm Peygamberi, II, 698, prg. 1127.

${ }^{80}$ Hamidullah, II, 698, prg. 1127; a.mlf., Kur'ân Tarihi, s. 42, 17.dipnot. Rivâyet için bkz. Taberânî, Ebû'l-Kâsım Süleyman b. Ahmed, el-Mu'cemu'l-kebîr, V, 142 (no: 4889), I-XX, Musul, 1404/1983; a.mlf., el-Mu'cemu'l-evsat, I-X, II, 257 (no: 1913), Kâhire 1415; Sem'ânî, Ebû Saîd Abdülkerim b. Muhammed, Edebu'l-imlâ ve'l-istimlâ, s. 77, Beyrut 1401/1981; Heysemî, Mecmau'z-zevâid, I, 152, VIII, 257. Abdülhamit Birışık da DİA "Kur'an" maddesinde, Hz. 
İbn Abbas'ın haber verdiğine göre Hz. Osman da vahyin yazımıyla ilgili olarak yaptı̆̆ açıklamada, Hz. Peygamber'e vahiy geldiği zaman kâtiplerden bir kaçını çă̆ırıp, onlara bu gelen âyetleri şu şu hususların zikredildiği sureye koyun dediğini haber vermiştir. ${ }^{81} \mathrm{Bu}$ ifadelerden de anlaşılan, tebliğden önce kitâbet görevi yerine getirilmekteydi.

Zerkânî de Rasûlullah'ın gelen âyetleri ezberlediğini, sonra vahiy kâtiplerine yazdırdığını ve insanlara tebliğ edip onların da ezberlediklerini söyler. ${ }^{82}$

Kanaatimizce, gelen âyetlerin kayda geçirilmesi indiği duruma ve konuma göre değişiklik arzetmektedir. Öyle zamanlar oluyordu ki Hz. Peygamber'e cevabını bilmediği bir soru soruluyor, bir müddet sonra vahiy geliyor, Rasûlullah da soru soranı yanına çağırıp sorunun cevabını veriyordu. ${ }^{83}$ Böyle bir durumda, gelen vahiyleri tebliğ etmek kitâbete göre öncelik kazanmış olmalıdır. Gecenin muhtelif saatlerinde gelen vahiylerde olduğu gibi vahyin insanlara hemen tebliğ edilmesinin zor olduğu zamanlarda da kitâbetin önce, tebliğin sonra olması mümkündür. Yani kitâbet ve tebliğden her ikisi de yerine göre öncelik kazanmış olabilir.

\section{Gelen Vahiylerin Yazıya Geçirilme Safhası}

Vahyin yazıya geçirilme hâdisesi bizzat Hz. Peygamber'in huzurunda gerçekleşiyor $^{84}$ yani vahiy kâtipleri önce ezberleyip sonra da yazma işlemini ezberlerinden ayrı bir mekânda yapmıyorlardı. Vahiy indiğinde Peygamber (a.s.) en son gelen âyetleri yazdırmak için düzenli olarak kâtiplerden birini çağırırdı. ${ }^{85}$ Zeyd b. Sabit'in evi Peygamber'in mescidine yakın olması nedeniyle vahiy geldiğinde sıklıkla kâtip olarak onun

Peygamber'in gelen vahiyleri öncelikle insanlara teblĭg ettiğini, ardından bunu vahiy kâtiplerine yazdırdığını kaydetmiştir. Bkz. XXVI, 385, Ankara 2002.

${ }^{81}$ Bkz. Ahmed, Müsned, I, 57 (no: 399); Ebû Dâvud, Salât 125 (no: 786); Tirmizî, Tefsîru'lKur'ân 10, (no: 3086, hasen-sahih demiştir); Nesâî, es-Sünenu'l-kubrâ, V, 10 (no: 8007); Hâkim, Müstedrek, II, 241 (no: 2875, Buhârî ve Müslim'in şartına göre sahih olduğunu söyler.). Müsned'in muhakkiki Ahmed Muhammed Şâkir, Tirmizî'nin hasen Hâkim'in sahih dediği bu rivâyetin, isnâdda bulunan Yezîd el-Fârisî sebebiyle ciddi derecede zayıf olduğunu hatta aslı olmadığını ayrıntılı olarak anlatmıştır. Bkz. el-Müsned li'l-İmâm Ahmed İbn Hanbel, I, 332-334, I-XX, Kahire 1416/1995. Benzer yorumları Müsned'i tahkik eden Şuayb el-Arnaût da tekrarlamıştır. Bkz. Müsnedu'l-İmâm Ahmed İbn Hanbel, I, 459-462, I-L, Beyrut 1416/1995.

${ }^{82}$ Bkz. Zerkânî, Menâhil, I, 217.

${ }^{83}$ Mesela bkz. Buhârî, Umre 10 (no: 1697); Müslim, Hac 6 (no: 1180).

${ }^{84}$ Bkz. Zerkânî, age., I, 222; Ebû Şehbe, Medhal, s. 338.

${ }^{85}$ Bkz. İbn Hacer, Fethu'l-bârî, IX, 22; Zerkânî, age., I, 203, dipnot; A'zamî, Kur'ân Tarihi, s. 107. 
çağırıldı ̆̆ı nakledilmektedir. ${ }^{86}$ Nitekim sonraları bunu hatırlatan Zeyd: "Biz Rasûlullah zamanında Kur'ân'ı telif ederdik" demiştir. ${ }^{87}$

Berâ b. Âzib'in rivâyet ettiğine göre Rasûlullah (لا يستوي القاعدون) âyetleriं $^{88}$ nâzil olduğu zaman Zeyd b. Sâbit'i çağırmış, o da elinde mürekkep, kalem ve yazı yazılacak malzemeyle gelmiş ve bu âyetleri yazmıştı. ${ }^{89}$ Bu rivâyet aynı zamanda her âyetin konulacağı yerin vahiy ile belirlendiğini de gösterir. Çünkü bu rivâyetin devamında yer alan bilgiye göre, Hz. Peygamber Zeyd'e bu âyetleri yazdırırken, âmâ sahâbî İbn Ümmi Mektûm bir şikâyetini dile getirmiş ve bunun üzerine nâzil olan cümlesi önceki âyetin arasına eklenmiştir. Sâbûnî, bu nedenle âyetlerin tertibinin tevkîfi olduğu konusunda âlimlerin ittifak ettiklerini belirtir. ${ }^{90}$

Âyetlerin Rasûlullah'ın huzurunda yazımı tamamlandığında, herhangi bir yazım hatası olmaması için yazılan âyetler Hz. Peygamber'e tekrar okunur; herhangi bir hata varsa düzeltilirdi. ${ }^{91}$ Vahiy kâtipleri, vahyi Rasûlullah'ın kendilerine yazdırdığı ve bildirdiği şekilde, en ufak bir değişiklik yapmaksızın harfi harfine yazıya geçirirlerdi. ${ }^{92}$

\footnotetext{
${ }^{86}$ Bkz. İbn Ebî Dâvud, Mesahif, s. 145 (no: 5); A'zamî, age., s. 107.

${ }^{87}$ Bkz. İbn Ebî Şeybe, Musannef, IV, 218, VI, 409 (no: 32466); Ahmed, Müsned, V, 184 (no: 21647); Tirmizî, Menâkıb 75 (no: 3954, hasen-garib diyor); İbn Hibbân, Sahîh, I, 320 (no: 114); Hâkim, Müstedrek, II, 249 (no: 2901), 668 (no: 4217, Buhârî ve Müslim'in şartlarına uygun olarak hasen-sahih olduğunu fakat onların tahric etmediği söylenmiștir.). Hâkim, ayrıca bu hadiste Kur'ân'ın Rasûlullah zamanında cem edildiğine açı delil olduğunu vurgulamıştır. Ancak rivâyetin metninde cem değil telif kelimesi geçtiği için, buradan Rasûlullah hayattayken Kur'ân'ın Mushaf haline getirilmiş olduğu gibi bir anlam çıkarmanın doğru olmadığı kanaatindeyiz. Nitekim Sâbûnî de burada söz edilen telifin, Allah'ın emri ve Rasûlullah'ın göstermesi ile âyetlerin tertip edilmesi olarak anlamıştır. Bkz. Tibyân, s. 72.

${ }^{88}$ Nisâ, 4/95.

${ }^{89}$ Bkz. İbn Ebî Şeybe, Musannef, IV, 226; Buhârî, Fezâilu'l-Kur'ân 4 (no: 4704); İbn Hibbân, Sahîh, I, 228 (no: 40). Hz. Peygamber'in Zeyd'i yazı malzemeleriyle çağırmış olması, kitâbetin bizzat Hz. Peygamber'in huzurunda yapıldığının açık bir göstergesidir. Aksi halde vahiy kâtipleri Peygamber'den öğrendiklerini ezberleyebilir ve daha sonra kayda geçirebilirlerdi.

${ }^{90}$ Bkz. Sâbûnî, age., s. 72. Müellif, bugün elimizde mevcut olan Mushaf'ın tertibinin Allah Teâlâ'dan gelen bir emir ve vahiy sonucu ortaya çıktığını; Hz. Peygamber'e gelen her âyetin nereye konulması gerektiğini Allah'ın emriyle Cibrîl'in beyan ettiğini, onun da buna göre sahâbeye öğrettiğini ifade eder.

${ }^{91}$ Bkz. Taberânî, Kebîr, V, 142 (no: 4888); a.mlf., Evsat, II, 257 (no: 1913); Heysemî, Mecmau'zzevâid, I, 152, VIII, 257; A'zamî, Kur'ân Tarihi, s. 107.

${ }^{92}$ Bkz. Ebû Şehbe, Medhal, s. 339.
} 
Vahiy yazan sahâbîlerden her biri bu işi, kendi gücü nispetinde yapmaya çalışıyor; nâzil olduğu şekilde muhafaza edebilmek için yazdıklarını muhtelif zamanlarda Hz. Peygamber'e okuyordu. ${ }^{93}$

Mekke dönemindeki ilk vahiy kâtibinin Abdullah b. Sa'd b. Ebî Serh olduğunu daha önce söylemiştik. Belâzurî, Medîne'ye geldiğinde Rasûlullah'a kâtiplik yapan ilk kimsenin ise Übeyy b. Ka'b el-Ensârî olduğunu, o bulunmadığı zaman Peygamber'in Zeyd b. Sâbit el-Ensârî'yi çağırdığını ve bu ikisinin Hz. Peygamber'in huzurunda vahyi, yazışmak istediği mektupları, ikta edilmiş şeyleri vs. yazdığını söylemektedir. ${ }^{94}$

Vahiylerin parçalar halinde gelmesi sebebiyle bunların, önce muvakkaten küçük eşyalar üzerine yazıldığ 1 , surenin tamamlanmasından sonra daha münasip diğer bir malzeme üzerine geçirilmek üzere bekletildiği belirtilir. ${ }^{95}$ Vahiyler yaygın olarak parşömen, papirüs, taş, hurma yaprakları, hayvanların kürek kemikleri, deri vb. malzemeler üzerine yazılmakla birlikte, Tâvus'tan nakledilen bir rivâyetten anlaşıldığına göre, onların ayakkabılara yazılması hoş karşılanmıyordu. ${ }^{96}$ Muhtemelen bu Allah kelâmına gösterilen saygıdan kaynaklanıyordu.

\section{Farklı Yazımların Ortaya Çıkışı}

Kur'ân'ı yazıya aktarma alışkanlığ 1 ashâb arasında çok yaygınd $1 .{ }^{97}$ Bunun tabii bir sonucu olarak gelen âyetlerin insanların ellerinde dolaşan birden fazla nüshaya yazıldığı anlaşılmaktadır. Nitekim Hz. Ebû Bekir'in hilâfeti esnasında bütün vahiy malzemesini tek bir Mushafta bir araya getirmesi için görevlendirilen vâhiy kâtibi Zeyd b. Sâbit ${ }^{98}$ her bir âyetin yazılı bir halde metne katılabilmesi için en az iki şahit ile ispatlanması ve sadece

93 Bkz. Kevserî, Muhammed Zâhid, Makâlât, s. 4, yy., ts.; Hamidullah, İslâm Peygamberi, II, 698, prg. 1127.

94 Bkz. Fütûhu'l-buldân, s. 693, prg. 1112.

${ }^{95}$ Hamidullah, Kur'ânı Kerîm Tarihi, s. 43, prg. 83; Demirci, Muhsin, Vahiy Gerçeği, s. 220.

${ }^{96}$ Bkz. İbn Ebî Dâvud, Mesâhif, I, 150 (no: 11).

${ }^{97}$ A'zamî, Kur'ân Tarihi, s. 107-108.

${ }^{98}$ Mesela bkz. Buhârî, Tefsîr 169 (no: 4402), Fezâilu'l-Kur'ân 4 (no: 4703). Montgomery Watt, Mekke'de normal olarak papirüsün kullanılmaması için herhangi bir neden bulunmadığı düşüncesinden hareketle, Ebû Bekir'in hilâfeti döneminde Kur'ân'ın parşömen veya papirüs parçalarından, taşlardan, hurma yapraklarından, hayvanların kürek kemiklerinden, deri ve tahta parçalarından toplandığına dair Zeyd b. Sâbit'ten nakledilen rivâyetin muhtemelen sahih olmadığını söylemiştir. Ona göre bu rivâyet, Emeviler dönemi ile Abbasilerin ilk dönemlerindeki maddi lükse karşı Hz. Muhammed ve ashâbının görece yoksulluğunu vurgulamak isteyen kişilerce yayılmış olmalıdır. Bkz. Kur'ân'a Giriş, s. 47. Bu açıklamanın ikna edici olmadığını düşünüyoruz. Ashâbın yoksulluğunu vurgulamak için böyle bir rivâyetin uydurulmasının ne gibi bir fayda temin edeceğini anlamış değiliz. 
hafizaya itimat edilmemesi emrini almışt. ${ }^{99}$ Bunun sonucunda ikisi hariç bütün âyetler için bu emir yerine getirilmiş; bu iki âyet için de sadece birer şahit bulunmuş, fakat bu âyetlerin doğruluğunu birçok kimse hafızasından teyit ve tasdik etmişti. ${ }^{100} \mathrm{Bu}$ durum da göstermektedir ki, vahyin yazımı resmî olarak vahiy kâtipleri eliyle sürerken, aynı zamanda bunun dışında da çeşitli gayelerle (tilâvet, hatıra vs.) âyetler bazı sahâbe tarafından yazılı bir şekilde muhafaza altına alınıyordu. ${ }^{101}$ Kanaatimizce öncelikle vahiy kâtiplerinden her biri Hz. Peygamber'in huzurunda yazılan vahiylerden kendisi için de birer kopya elde etmiş, hatıra amaçlı onları saklamış ve cemedilmesi esnasında Zeyd b. Sâbit'e getirmiş olabilir.

Bununla birlikte, ellerinde yazılı Kur'ân nüshaları olan herkeste Kur'ân'ın baştan sona tamamının yazılı olarak bulunduğunu düşünmek pek mümkün olmasa gerek. Yani birinde yazılı olarak bulunan âyetler bir başkasının nüshasında bulunmayabiliyordu. Çünkü sahâbenin tamamının vahyin yazımını düzenli olarak takip edebilmesi pratikte mümkün değildi. Herkesin meşgul olduğu bir işi vardı, Hz. Peygamber'e ne zaman vahiy geleceğini kimse kestiremezdi; mesela onun yolculuğunda gelen vahiylerden birinin haberi olurken, diğerinin hiç haberi olmayabiliyordu. ${ }^{102}$ Hamidullah'ın işaret ettiği gibi, ilk devrin bütün Müslümanları aynı entelektüel yapı ve kabiliyette değillerdi. Hz. Peygamber de, inen vahiylerden nüshalar edinmeleri hususunda istisnasız herkesi bir tutmadı. Çünkü bazılarının okuma yazması yoktu, bazıları hayatlarını kazanma hususunda pek meşgul, diğer bazıları da her gün inip gelen yeni vahiylerden haberdar olacak kadar Peygamber'in oturduğu yere yakın yerlerde ikamet etmiyorlardı. Esasen bu vahiylerden bazılarının inişi, onun seyahat halinde olduğu zamanlara da rastlayabiliyordu. İşte bütün bunlar, hiç kimsenin Kur'ân'ın tamamının yazılı metnine esasen sahip olamayacağını bize izah eder. Daha Hz. Muhammed'in sağlığında iken bile bazı yazılı parçalar bazı sahâbîlerde,

99 Bkz. İbn Ebî Dâvud, Mesâhif, I, 157 (no: 23).

100 Bkz. Hamidullah, II, 702, prg. 1129. Söz konusu iki âyetin Tevbe suresinin son iki âyeti olduğunu ve Zeyd b. Sâbit'in bu âyetleri sahâbeden sadece Ebû Huzeyme el-Ensârî'de bulabildiğini öğreniyoruz. Bkz. Buhârî, Tefsîr 169 (no: 4402), Fezâilu'l-Kur'ân 4 (no: 4703); Ebû Ya'lâ, Müsned, I, 72 (no: 71); İbn Hibbân, Sahîh, X, 360; Beyhakî, Şuabu'l-îmân, I, 195 (no: 171).

101 Draz, Mekke'de vahiy yazımı işiyle görevli fazla kimse olmamakla ve bu vazife de resmî bir özellik taşımamakla beraber, müminlerin ta baştan beri hatta zulüm altında bile, kendi şahsi ihtiyaçları için Kur'ân âyetlerini istinsah etmekten geri kalmadıklarını düşünür. Bkz. Draz, Abdullah, Kur'ân'ın Anlaşılmasına Doğru, s. 28-29, trc. Salih Akdemir, Mim Yayınları, y.y., 1983.

102 Bkz. Zerkânî, Menâhil, I, 203; Mennâu'l-Kattân, Mebâhis, s. 119. 
diğer yüzlerce yazılı âyet veya sure parçaları da diğerlerinde bulunabiliyordu. ${ }^{103}$

Kendileri için Kur'ân âyetleri yazan bazı sahâbîler, aynı malzemeye âyet olmayan bir şey de yazabiliyorlar ve onlar bunun âyet olmadı̆̆ını biliyorlardı. Ancak kanaatimizce bu tür yazılar o âyetlerde geçen bazı kelimelerin tefsiri kabilinden yahut ilgili âyetin içeriğiyle ilgili dua türünden ifadelerdi. ${ }^{104} \mathrm{Bu}$ Kur'ân nüshaları kendilerine ait olduğu için, alınan bu tür notları normal karşılamak gerekir. Bu cümleden olarak İbn Mes'ûd ve $H z$. Ali gibi vahiy kâtipliği yapan sahâbîlerden bazısının kendine has Mushafları vardı. ${ }^{105}$ Hamidullah, Kur'ân-1 Kerim'e dâhil olan ilâhî âyetleri yazıyla tespit için bizzat Rasûlullah tarafından tayin edilmiş kâtipler olan, mesela aralarında bir yandan Ebû'd-Derdâ ve İbn Mes'ûd, diğer yandan Zeyd b. Sâbit de bulunan yaşlı sahâbîlerin, kıdemsiz genç vahiy kâtiplerine tâbi olup onlara teslimiyet göstermek istememelerinden doğan bir takım önemsiz kayıt ve tespit farkları (variant'lar) ortaya çıkabileceğini düşünmekte; fakat bu yazıyla tespit farklarının çoğunlukla hayatî önem taşımayan farklılıklardan ibaret olduğunu belirtmektedir. ${ }^{106}$

\section{Yazılan vahiylerin tamamı $\mathrm{Hz}$. Peygamber'in evinde yazılı olarak muhafaza ediliyor muydu?}

Bu konuda bir görüş birliği yoktur. Hamidullah'a göre, "resmî" vahiy kâtipleri tarafından kaydedilip nüshaları çıkarılan âyet metinleri, Rasûlullah tarafından saklanmış olmayıp vahiyleri yazan bu kâtipler tarafından muhafaza edilmiş ve kopya edip bunlardan nüsha çıarmak isteyen kimselerin bu arzularını yerine getirmelerine daima müsaade

103 Hamidullah, Kur'ânı Kerîm Tarihi, s. 43-44, prg. 84.

104 Bkz. Zerkânî, Menâhil, I, 222. Hamidullah da şunları söyler: "Öyle gerçek durumlar ortaya çıktı ki, ellerinde Kur'ân ile ilgili bazı âyet metinleri olup da burada geçen bazı kelimelerin açıklanması ve tefsiri konusunda bizzat Rasûlullah'tan duyduğu bilgileri unutmamak gayesiyle metnin kenarlarına (hâşiyelere) bunları yazıyla ilave eden kimselere ait bazı Kur'ân parçaları, bu gibi haller ender de olsa, daha sonraki nesiller tarafından bu eklerle (hâşiyelerle) birlikte âyet metni sanılmış ve Kur'ân metnine dâhil edilmişlerdir. Şüphesiz pek ender de olsa, yine öyle durumlar vardır ki bunlar, yukarda işaret ettiğimiz ne Arapçanın ağız farkları ve ne de metin kenarı açıklamaları (hâşiyeler) gerçeği ile izah olunabilirler. Mesela en itimada değer kaynaklardan biri olan Buhârî́nin Tefsîr adlı eserinde de belirtildiği gibi Kur'ân-1 Kerim'in 92/3. âyetini önceleri Rasûlullah (والذكر والأنثى) şeklinde tilâvet ettiği halde daha sonra aynı ibareyi (وما خلق الذكر والأنتى) olarak kıraat etmeye başlamıştı..." Bkz. Hamidullah, İslâm Peygamberi, II, 699-700, prg. 1127. Krş. Buhârî, İsti'zân 38 (no: 5922).

105 Bkz. Sâbûnî, Tibyân, s. 71.

106 Bkz. Hamidullah, age., II, 700, prg. 1127. 
olunmuştur. ${ }^{107}$ Onun konuyla ilgili ifade tarzı önemli olduğu için aynen vermek istiyoruz:

"Bu konuda çeşitli hadisler tetkik edilip bir arada mütalaa edilecek olursa, Zeyd'in çalışmaları arasında, şeklî olarak Kur'ân'ın sadece yazıya geçmiş parçalarını arayıp bunların peşinde koşmadığ ${ }_{1}$ ve fakat aynı zamanda bu yazılı metinlerin Hz. Peygamber'in etrafındakilere bizzat imla ettirdiği ilk el yazılar olmasına da itina gösterdiği intibaı bizde uyanır. Hatta bir hadiste nakledildiğine göre Hz. Ebû Bekir bu çalışmalar sırasında Rasûlullah'ın evinde, çok sayıda sahifeler bulmuş ve bunları bir ip vasıtasıyla bir tomar halinde paketlemişti. Anlaşıldığına göre bu sonuncu durumda, bütün halinde ve Kur'ân'ın tamamını içine alan bir müdevvenat söz konusu edilemez; şayet böyle olsaydı halk arasında dağınık vaziyette bulunan Kur'ân parçalarını arayıp bulma ve bir araya getirme zahmetine girişilmezdi." ${ }^{108}$

Draz bunu daha kesin bir dille ifade etmiş ve Hz. Peygamber'de yazılı tek bir âyet bile olmadı̆̆ını, başkalarında da tam bir nüsha bulunmadığını, müminler arasında bu şekilde yayılmıș olan Kur'ân'ın tam ve kesin şeklini hâfızalarda, ancak Hz. Peygamber'in hayatının sonuna doğru aldığını söylemiştir. ${ }^{109}$

Bazı araştırmacılar ise yazılanların bir nüshasının Hz. Peygamber'in evinde bulunduğu kanaatindedir. Bunlardan birine göre, Rasûlullah'ın tashihinden geçen Kur'ân metni, yine onun emriyle çoğaltılıyor, Müslümanların bir kısmı bu çoğaltılan nüshaları alıyor, bir kısmı da tashih edilen metinden kendileri için yazıyorlardı. İstinsah işi bittikten sonra da mukâbele gören asıl nüsha Rasûlullah'a teslim edilip hâne-i saadette muhafaza ediliyordu. ${ }^{110}$

107 Bkz. Hamidullah, age., II, 700-701, prg. 1128.

108 Hamidullah, Kur'ân-ı Kerim Tarihi, s. 49. Onun buna benzer diğer bir değerlendirmesi şöyledir: "Hz. Ebû Bekir'in bağlattığı bu sahifeler, tam bir Kur'ân nüshası değildi. Şayet öyle olsaydı Hz. Ebû Bekir, Zeyd b. Sâbit'in başında bulunduğu Kur'ân'ı cemetme komisyonunu kurmazdı. Öyle anlaşlıyor ki bu sahifeler Hz. Peygamber'e aitti. En çok itimat edilecek nüsha da bu olmalıydı. Belki de Hz. Peygamber kendisine ait bir Kur'ân nüshası temin etmek istemiş ve bunu birine yazdırmış, fakat tamamlanmadan vefat etmişti. Muhtemelen bu fikir Hz. Peygamber'e çok sonraları gelmişti. Zira önceden böyle bir düşüncesi olsaydı, hususi nüshası da tamamlanmış olurdu." Bkz. Demirci, Vahiy Gerçeği, s. 227, Hamidullah'ın Kur'ân-ı Kerim Tarihi Ders Notları, s. 19'dan naklen.

109 Draz, Kur'ân'ın Anlaşılmasına Doğru, s. 29.

110 Bkz. Demirci, Vahiy Gerçeği, s. 220. Yazılan malzemenin bir suretinin Rasûlullah'ın evinde muhafaza edildiğini ve bir suretinin de vahiy kâtipleri tarafından kendileri için yazıldığını savunan bir görüş için bkz. Öztürk, Hayrettin, Ebedî Mucize Kur'ân- Yazılması ve Toplanması, s. 52, Istanbul 2005. Muhsin Demirci, vahiy kâtipleri tarafından yazılan her metnin tashih edildikten sonra Hz. Peygamber'in evinde muhafaza edilmekte olduğuna dair görüşünü, Hz. 
Zerkanî'ye göre de, vahiy kâtipleri Kur'ân âyet ve surelerini yazdıktan sonra yazılı malzemeyi Hz. Peygamber'in evine koymaktaydı. ${ }^{111}$ Ancak o bu sözlerini herhangi bir rivâyete dayandırmamakla ve bu konuda bir kaynak göstermemekle tenkit edilmiştir. ${ }^{112}$ Günümüz araştırmacılarından Ersöz'e göre, vahiy kâtiplerinin yazdıklarını Hz. Peygamber'in evine koymaları hususu Hâris el-Muhâsibî'nin (ö.243/857) sözlerinden kaynaklanmaktadır. el-Muhâsibî'nin Fehmü's-sünen adlı eserinde söylediği belirtilen sözler ${ }^{113}$ şöyledir:

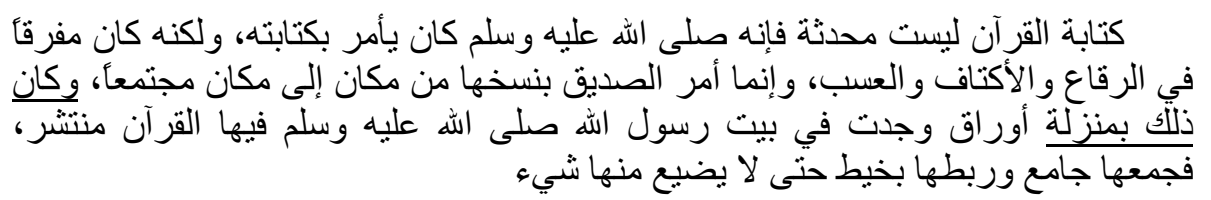

Sanırız görüș ayrılıklarının çıkış noktası bu ibarenin nasıl anlaşıldığıyla ilgilidir. Ersöz bu metni şöyle çevirmiştir: "Kur'ân'ın yazılması yeni bir şey değildir. Çünkü Peygamber (s.a.) onun yazılmasını emrediyordu. Fakat o ince derilerde, kemiklerde ve hurma yapraklarında dağınık bir vaziyette idi. (Ebû Bekir) es-Sıddîk ancak bir araya getirmek için onun bir yerden bir yere kopya edilmesini emretti. Bu da birinin; Rasûlullah'ın evinde bulunan ve üzerlerinde dağınık bir vaziyette Kur'ân'ın yazılı olduğu kâğıtları, onlardan hiçbir şey kaybolmasın diye, toplaması ve onları bir iple bağlamasına benzer."114

Ebû Bekir'in Kur'ân'ın toplanması esnasında Rasûlullah'ın evinde çok sayıda yazılı metin bulup bunları iplerle paketler haline getirttiğini gösteren bir rivâyete dayandırmaktadır (s. 226-227). Ancak birazdan göreceğimiz gibi gerçekte böyle bir rivâyet yoktur. Bununla birlikte Demirci, olayların cereyan tarzının Hamidullah'ı haklı çıkardığını itiraf ederek kendi görüşünü nakzeder gibidir. Bkz. Vahiy Gerçeği, s. 227, 228.

111 Zerkânî, Menâhil, s. 202

112 Bkz. Ersöz, Kur'ân Tarihi, s. 79. Yazarın ifadelerine göre, Subhi es-Sâlih de aynı şekilde rivâyet belirtmeden ve kaynak göstermeden, Kur'ân'dan yazılan her şeyin Hz. Peygamber'in evine konulduğunu zikretmiş; Ramazan el-Bûtî ise vahiy kâtiplerinin Kur'ân'dan yazdıklarını Peygamber'in evine koydukları hususunu el-Muhâsibî'nin Fehmü's-Sünen adlı kitabında zikrettiğini açıladıktan sonra Zerkeşînin el-Burhân'ını ve Suyûtî'nin el-İtkân'ını referans olarak vermiştir.

113 Bkz. Zerkeşî, el-Burhân fî̀ ulûmi'l-Kur'ân, I, 332, I-IV, Beyrut 1410/1990; Suyûtî, el-ìtkân fî ulûmi'l-Kur'ân, I, 185, I-II, Beyrut 1414/1993.

114 Bkz. Ersöz, age., s. 80-81. Caetani ise el-Muhâsibî'nin sözlerinden şu şekilde bahsetmektedir: "Hâris el-Muhâsibî'ye göre Peygamber Medine'de bulunduğu müddetçe bütün Kur'ân'ı tahrîran zapt ettirmişti. Bir cilt halinde değildi, ayrı ayrı kâğıt yaprakları (rikâ'), deve kemikleri (kürek kemikleri, ektâf) ve hurma dalları üzerine yazdırmıştı. Peygamberin hîn-i vefatında bunlar ikâmetgâhında karma karıșık bir halde bulundu. Ebû Bekir bütün bunları (hep aynı cesamette) sahifeler üzerine istinsâh etmek ve hiçbirinin ziyâına meydan 
O, bu sözlerden anlaşıldığı kadarıyla Hâris el-Muhâsibî'nin bir benzetme yaptığını; dolayısıyla bu benzetmeye dayanarak, Rasûlullah'ın

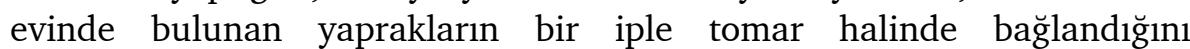
çıkarmanın doğru bir anlayış olmadığını belirtir. ${ }^{115}$ Bu anlayışı biz de benimsiyoruz. Konuyla ilgili olduğu söylenen rivâyet Hâris elMuhâsibî'nin sözlerinin yanlış anlaşılmasından kaynaklanmaktadır. Dolayısıyla bu sözlere dayanarak Rasûlullah'ın evinde muhafaza edilen bir nüshadan söz etmek mümkün görünmemektedir. Ancak yazılı bazı metinlerin Hz. Peygamber'in evinde bulunabileceğini, belki bunların daha sonra vahiy kâtiplerine tevdi edilip onlar tarafından muhafaza altına alındığını düşünebiliriz.

\section{Vahiy Kâtipliği Yaptığı Söylenen Kişiler}

Rasûlullah'ın peygamber olarak gönderildiği zaman diliminde yazı bilenlerin sayısının son derece sınırlı olduğu bildirilir. ${ }^{116}$ Bu bilginin doğru olması durumunda -ki aksi yönde değerlendirmeler de vardır- ${ }^{117}$ sınırlı sayıdaki bu kişilerin daha ilk başta hepsinin de Müslüman olmadığı

vermemek üzere bir cilt halinde bir yere dikmek için emir verdi." Bkz. Caetani, İslâm Tarihi, IX, 177, prg. 227.

115 Ersöz, age., s. 84. Ayrıca böyle bir konuda öncelikle erken dönem hadis kaynaklarında yeterli bilgi bulunması gerektiği, ancak henüz böyle bir bilgiye ulaşılamadığı, bütün bunlarla birlikte, yazılan malzemelerin tam ve bütün olarak Hz. Peygamber'in evine konulmuş olduğunu kesin bir şekilde ispat etmek zorsa da, bir kısmının Hz. Peygamber'in evinde bulunabileceğini inkâr etmek de mümkün olmadı̆̆ı yazar tarafından ifade edilir.

116 Belâzurî, İslâm geldiğinde Kureyş kabilesinde yazı yazabilen 17 kişinin isimlerini şöyle kaydetmiştir: Ömer b. el-Hattab, Ali b. Ebî Talib, Osman b. Affan, Ebû Ubeyde b. el-Cerrah, Talha, Yezid b. Ebî Süfyan, Ebû Huzeyfe b. Utbe b. Rebîa, Hâtıb b. Amr, Ebû Seleme b. Abdilesed el-Mahzumî, Eban b. Said b. el-Âsî b. Ümeyye, kardeşi Hâlid b. Said, Abdullah b. Sa'd b. Ebî Serh el-Âmirî, Huveytib b. Abdiluzza el-Âmirî, Ebû Süfyan b. Harb b. Ümeyye, Muaviye b. Ebî Süfyan, Cüheym b. el-Salt b. Mahrame ve el-Alâ b. el-Hadramî. (Bkz. Fütûhu'l-buldân, s. 660-661; çevirisinden s. 691-692, prg. 1104). Okuma-yazma bilenlerin 17'si erkek, 7'si kadın toplam 24 kişi olduğu hakkında bilgi için bkz. Yılmaz, Metin, İslâm Kitâbet Dairesinin Doğuşu ve Gelişmesi, s. 15, Yüksek Lisans tezi, Ondokuz Mayıs Ü. SBE., Samsun 1998.

117 Mesela Watt, Mekke'de sıradan insanların bile yazıdan haberdar olduğuna dair bir takım değerlendirmelerde bulunmuştur. Geniş bilgi için bkz. Kur'ân'a Giriş, s. 46 vd. F.Buhl ise, Mekke ile Medine'de yazının yaygın olduğu hakkında anlatılanları ihtiyatla karşılamak gerektiği; bununla birlikte Mekke gibi önemli bir ticaret şehrinde, milletlerarası münasebetler ile az çok iyi yazı yazan bir hayli kimsenin bulunduğundan da şüphe edilemeyeceği kanaatindedir. Bkz. İA, "Kur'an" md. VI, 1000. B.Moritz de yazıyı yalnız 17 erkek ile birkaç kadının bildiğine dair Belâzurî'deki rivâyetin pek sıhhatli görülmediğini, çünkü sadece Peygamber'in beş-on kâtibi olduğunu, eski bir ticaret merkezi olan Mekke'de üzerine yazı yazmak için türlü türlü maddeler kullanılmış olmasının yazı bilenlerin çokluğunu gösteren bir delil teşkil ettiğini söyler. Bkz. İslâm Ansiklopedisi, I, 499, "Arap Yazısı" md., İstanbul 1942. 
düşünülecek olursa, İslâm'ı tercih etmiş kişilerden yazma işini bilenlerin sayısının bir elin parmaklarını geçmeyeceğini varsayabiliriz. Dolayısıyla, önceleri Rasûlullah'ın vahyin yazımında kullanabileceği kişilerin çok az olduğu anlaşılmaktadır. Sonraki dönemde ise sahâbeden pek çok kişi kitâbet işinde bir şekilde yer almıştır. Hatta Kur'ân âyetlerini Peygamber'in emri olmaksızın kendileri için yazanlar da olmuştur. ${ }^{118}$

Belâzurî, Rasûlullah Medîne'ye geldiğinde ona kâtiplik yapan ilk kimsenin Ubeyy b. Ka'b el-Ensârî olduğunu, o bulunmadığı zaman Peygamber'in Zeyd b. Sâbit el-Ensârî'yi çağırdığını ve bu ikisinin Hz. Peygamber'in huzurunda vahyi, yazışmak istediği mektupları, ikta edilmiş şeyleri vs. yazdığını söylemektedir. ${ }^{19}$

İbn Kesîr, vahiy kâtipleriyle ilgili olarak açtığı uzun bölümde bu işle meşgul olanları tek tek saymıştır. ${ }^{120} A^{\prime} z a m \hat{\imath}$ de, Medine dönemi hakkında Peygamber'e şu veya bu zamanda kâtiplik yapmış yaklaşık 65 sahâbenin isimlerini de içeren bir bilgi zenginliğine sahip olduğumuzu söyler. ${ }^{121}$

Hiç şüphesiz sıralanan isimlerin hepsinin de sürekli vahiy yazma işiyle meşgul olduklarını düşünmek doğru olmasa gerek. Bunların çoğunun belki de birkaç âyetin yazımında yahut istinsahında isimleri geçtiği için vahiy kâtipleri arasında sayılmış olması muhtemeldir. Rasûlullah'ın yanında sürekli vahiy kitâbeti işiyle uğraşan ve asıl bu işte zikredilmesi gereken kişilerin çok da fazla olması gerekmez. Özellikle Zeyd b. Sâbit ve Übeyy b. Ka'b'ın bunların başında geldikleri anlaşılıyor. Hz. Ebû Bekir'in vahiy malzemelerinde ve diğer insanlarda dağınık bir şekilde bulunan vahiyleri bir Mushafta toplaması için, adı geçen diğer

118 Bkz. Mennâu'l-Kattân, Mebâhis, s. 118. Rasûlullah'ın emri olmaksızın yazılan bu Kur'ân nüshalarının hatıra için veya tilâvet gibi ihtiyaçlarını karşılama amaçlı olarak yazıldığını düşünebiliriz. Yani gelen vahiyleri herkesin kendi istediği gibi kayda geçirdiği ve bu konuda Peygamber'den izin alma gereğini hissetmediği şeklinde anlamamak icap eder. Bu durumda yazılanların yine Zeyd b. Sâbit ve diğer ehil kişilerce mutlaka gözden geçirilmiş olması gerekir.

119 Bkz. Fütûhu'l-buldân, s. 693, prg. 1112.

120 Bkz. es-Sîretu'n-Nebeviyye, IV, 669-697. Ancak müellif burada sadece vahiy kâtipliği yapanları değil iktâ, emân vb. diğer işlerde kâtiplik yapanları da karışık olarak vermiştir. Onun sıraladığı isimler şunlardır: Dört halife, Ebân b. Saîd, Übeyy b. Ka'b, Erkam b. Ebî'lErkam, Sâbit b. Kays, Hanzala b. er-Rabî', Hâlid b. Saîd, Hâlid b. el-Velîd, Zübeyr b. elAvvâm, Zeyd b. Sâbit, Sicill (şüpheli olduğunu söyler), Âmir b. Füheyre, Abdullah b. Erkam, Abdullah b. Zeyd, Abdullah b. Sa'd b. Ebî Serh, el-Alâ b. el-Hadramî, el-Alâ b. Ukbe, Muhammed b. Mesleme, Muâviye b. Ebî Süfyân ve Muğîre b. Şu'be. Bu sayılan isimlerin Hz. Peygamber'in emriyle ve onun huzurunda kâtiplik yaptıkları müellif tarafından ifade edilir. Bkz. age., IV, 697.

121 Bkz. Kur'ân Tarihi, s. 106. 
bütün isimler bir yana Zeyd b. Sâbit'e görev vermesi de bu görüşümüzü teyit eder.

\section{Sonuç}

İncelemelerimiz sonucu gördük ki, Kur'ân âyetlerinin yazılması İslâm'ın erken dönemlerinde başlamıştır. Tahminlerimize göre bu vahyin geldiği ilk bir kaç yıl içinde olabilir. Hem âyetlerden hem de ilgili rivâyetlerden böyle bir sonucu çıkarma imkânımız vardır. İkinci olarak; vahiy kâtipleri, Hz. Peygamber'den duyduklarını bizzat onun huzurunda ve aynen kayda geçiriyorlardı, daha sonra yazılan metin kontrol ediliyordu. Dolayısıyla hadislerin mana ile rivâyet edilmesine karşlık, âyetler hakkında sadece mana olarak yazılması ve aktarılması gibi bir düşüncenin ortaya çıkması mümkün değildir. Yine hadislerin yazımının belli bir süre en azından ehil olmayanlara yasaklanmasına mukabil, vahyin yazımı hiçbir zaman, hatta yolculukta bile sekteye uğramamış, ayrıca isteyenlerin kendileri için yazılı nüshalar temin edilmesine müsaade edilmiştir. 